\title{
THE SUNGAI BATU ARCHAEOLOGICAL COMPLEX: RE-ASSESSING THE EMERGENCE OF ANCIENT KEDAH
}

\author{
Nasha Rodziadi Khaw ${ }^{1 *}$ and Gooi Liang Jun ${ }^{2}$
}

${ }^{1}$ Centre for Archaeological Research Malaysia, Universiti Sains Malaysia, Pulau Pinang, MALAYSIA

2Taylor's School of Architecture, Building and Design, Taylor's University, Selangor, MALAYSIA

"Corresponding author: rnasha@usm.my

Published online: 29 October 2021

To cite this article: Nasha Rodziadi Khaw and Gooi Liang Jun. 2021. The Sungai Batu Archaeological Complex: Re-assessing the emergence of Ancient Kedah. Kajian Malaysia 39(2): 117-152. https://doi.org/10.21315/km2021.39.2.6

To link to this article: https://doi.org/10.21315/ $\mathrm{km} 2021.39 .2 .6$

\begin{abstract}
This article proposes new historical perspectives arising from the findings in the Sungai Batu Archaeological Complex, Kedah, by the Centre for Global Archaeological Research, Universiti Sains Malaysia in 2009. Excavations in the complex unearthed the remains of iron smelting sites, wharves and other brick structures, dating back to the $2 \mathrm{nd} / 3 \mathrm{rd}$ century $\mathrm{AD}$. The discoveries of furnaces, tuyeres and iron slag attest to Sungai Batu's role as the centre for primary iron production, employing the bloomery method. The study suggests that Ancient Kedah appeared as one of the hubs for the trans-Asiatic trade network with the rise of the iron industry, while its economic complexity grew steadily in successive centuries. The early emergence of Ancient Kedah was a development synchronous with the later phase of the Indian-Southeast Asian exchange network between the 2nd to the 4th century AD when inter and intra-regional trade intensified. Due to its favourable geological features, strategic location with a suitable ecozone, as well as being a thriving centre for primary iron production, Ancient Kedah emerged as an important harbour. It was this trading and industrial past, the article will argue, that contributed to the rise of other economic hubs within Ancient Kedah, such as Pengkalan Bujang and Kampung Sungai Mas, which eventually developed into entrepôts after the 5th century $A D$.
\end{abstract}

Keywords: Sungai Batu Archaeological Complex, Ancient Kedah, iron industry 


\section{INTRODUCTION}

Ancient Kedah was a group of various settlements and exchange sites located in the Bujang Valley, which developed as a polity from the 2nd to 14th century AD. Different hypotheses on how Ancient Kedah emerged have been proposed by Quaritch-Wales (1940), Lamb (1961), Nik Hassan Shuhaimi (1984), Allen (1988) and Hergoualc'h (2002). Lamb, Nik Hassan Shuhaimi and Hergoualc'h each suggested that Ancient Kedah became a seaport after the 5th century AD. This development was said to have been caused by the arrival of Buddhist traders from the Indo-Pakistan subcontinent, whose religion influenced the locals. Their arguments have been strongly based on several sculptures and inscriptions found in the Muda River valley. However, these cultural remains could directly attest only to the presence of Buddhist communities during that period. Quaritch-Wales and Allen on the other hand placed the emergence of Ancient Kedah in the $2 \mathrm{nd} / 3$ rd century AD. However, their arguments have not been supported by any direct archaeological evidence found in the Bujang Valley. Although the Tamil and Sanskrit literatures such as Pattinappalai, Sillappadikaram and the Jataka stories do give some hints about Ancient Kedah's economic significance before the 5 th century $\mathrm{AD}$, these records only made passing remarks and have not been taken very seriously, as their descriptions could not be attested by direct archaeological evidence.

The archaeological mounds and surface finds in the Sungai Batu Archaeological Complex were first reported by Jane S. Allen (1988) as sites no.71, 72 and 73. During a palaeo-environmental survey in 2007, the archaeological team of the Centre for Global Archaeological Research (CGAR) mapped at least 97 mounds in the same area. The first systematic excavation in 2009 uncovered religious and iron smelting sites, named SB1B and SB2A, respectively. Iron smelting sites were considered a new discovery, as they had not been uncovered in areas previously studied in the Bujang Valley. Further excavations revealed brick structures as well as more remains of iron smelting activities. The discovery of furnace fragments, iron slag and tuyeres (air conduits) gave important insights into the iron smelting technology of Sungai Batu, showing similar assemblage with those found in South India, Myanmar and Thailand (Nitta 1997; Sasisekaran 2002; Hudson 2012; Johansen 2014). The types of iron ores used in the smelting process were mostly hematite and magnetite, minerals which could be found within a $5 \mathrm{~km}$ radius from the site. Among the areas abundant in iron ores which are located near to Sungai Batu include Bukit Tupah, Semeling, the Universiti Teknologi MARA (UiTM) campus and Kampung Besi (Nordianah 2013). The rediscovery of the Sungai Batu Archaeological Complex by the CGAR, 
Universiti Sains Malaysia has given fresh insights into the economic role played by Ancient Kedah.

By reviewing and re-analysing the archaeological finds at Sungai Batu, this article proposes the synchronicity between the rise of iron smelting industry in the Sungai Batu Archaeological Complex with the emergence of Ancient Kedah as a port-industry.

\section{SUNGAI BATU ARCHAEOLOGICAL COMPLEX}

One important aspect of the study on Ancient Kedah involves the research concerning its chronology, cultural sequence and periodisation. The archaeological findings at Sungai Batu suggest the position of the area as a polity or settlement specialising in primary iron production, which involved the activities of iron mining and smelting. The dating results from the sites of Sungai Batu, namely SB2A, SB2H, SB2F, SB1ZY and SB1G, can potentially give important clues regarding the emergence of Ancient Kedah, especially before the 5th century CE.

From these 5 sites, 73 radiocarbon and accelerator mass spectrometry (AMS) dates were available for study. For sites such as SB2H, SB2A and SB2F, the Bayesian method for analysing the Carbon-14 $\left({ }^{14} \mathrm{C}\right)$ data could be applied as there was a large enough number of ${ }^{14} \mathrm{C}$ samples for radiocarbon and AMS dates. There were 17 samples from site SB2H, 19 samples from site SB2A, and 29 samples from site SB2F (refer Appendix: Tables 1, 2 and 3). As for sites SB1G and SB1ZY, only four radiocarbon and AMS dates were available from each site (refer Appendix: Table 4). Although some ideas regarding the age of sites SB1G and SB1ZY were available, the number of dates was far too small for meaningful Bayesian analysis. As opposed to Frequentist statistics where large trials are required to test the probability in archaeological analysis, the Bayesian method can be applied to study the accuracy of the ${ }^{14} \mathrm{C}$ dates even when only a relatively small number of samples are present. The Bayesian method can coherently analyse absolute dates from different cultural layers. It helps in identifying underlying date-ranges via radiocarbon readings, pointing out outlier dates and performing the necessary calibrations (Buck and Juarez 2017). In this article, the AMS and radiocarbon dates were analysed by using the OxCal programme version 4.3 which provided the calibration and analysis. This online chronological modelling software was developed based on Bayesian theorem by Christopher Bronk Ramsey. The programme can provide a simultaneous 
comparison of ${ }^{14} \mathrm{C}$ datings from different stratigraphic layers as well as constructing an inclusive and contextual chronological model. This off-theshelf Bayesian algorithm modelling software is commonly used in analysing ${ }^{14} \mathrm{C}$ dates to deduce the ideal age range of archaeological sites (Ramsey 2009).

The ${ }^{14} \mathrm{C}$ dating was carried out on various charcoal samples found through excavation at the iron smelting sites, namely SB2A, SB2H, SB2F, SB1ZY and SB1G. The radiocarbon and AMS dates have already been published in the masters and doctoral theses by Naizatul Akma (2012; 2019). The charcoal samples were reported to have been associated with the remains of iron smelting activities, such as tuyeres, iron slag, iron ores and fragments of iron furnaces (refer Appendix: Tables 1, 2, 3 and 4). For this paper, the attempt to establish detailed chronological phases and boundaries for sites SB2A, SB2H and SB2F were hindered by the quality of the available data. The lack of sufficient information regarding the context and nature of the samples was due to Bayesian chronological modelling not being considered before the collection of dating samples. The sampling strategy did not entirely follow Bayesian chronological modelling, which should have also involved constructing a simulation model for the chronology of the sites as well as determining the matrix and structural phasing of the sites (Bayliss 2009). Furthermore, the stratigraphic relationships between most of the samples were unclear, where they could only be viewed as a relatively continuous phase of activity. Consequently, this study lacks a robust evaluation regarding the relationships between samples with contexts, as well as between samples with other samples. For the data sets available to us, the application of the Bayesian method could suggest rough estimates regarding the beginning and end of the period of occupation as well as iron smelting activities at the sites. While acknowledging these limitations, three multiple plots were produced for each site, namely SB2H, SB2A and SB2F. Before analysing the data in the $\mathrm{OxCal} 4.3$, all of the ${ }^{14} \mathrm{C}$ dates were arranged according to their respective spit levels.

For site SB2H, 17 AMS dates of charcoal samples taken from 5 spits were analysed (refer Appendix: Table 1). The initial model had a poor overall agreement between the AMS dates and the archaeological sequence. Four dates of poor individual agreement in the model (516412, 410260, 401263 and 517676) were excluded from the analysis and the model was re-run (see Figure 1). Aside from the four dates which were already excluded, the AMS date 516413 (788-537 BC) also appeared to have been an outlier, as samples dated between the 6th century $\mathrm{BC}$ to the 2 nd century $\mathrm{AD}$ had not yet been reported. 


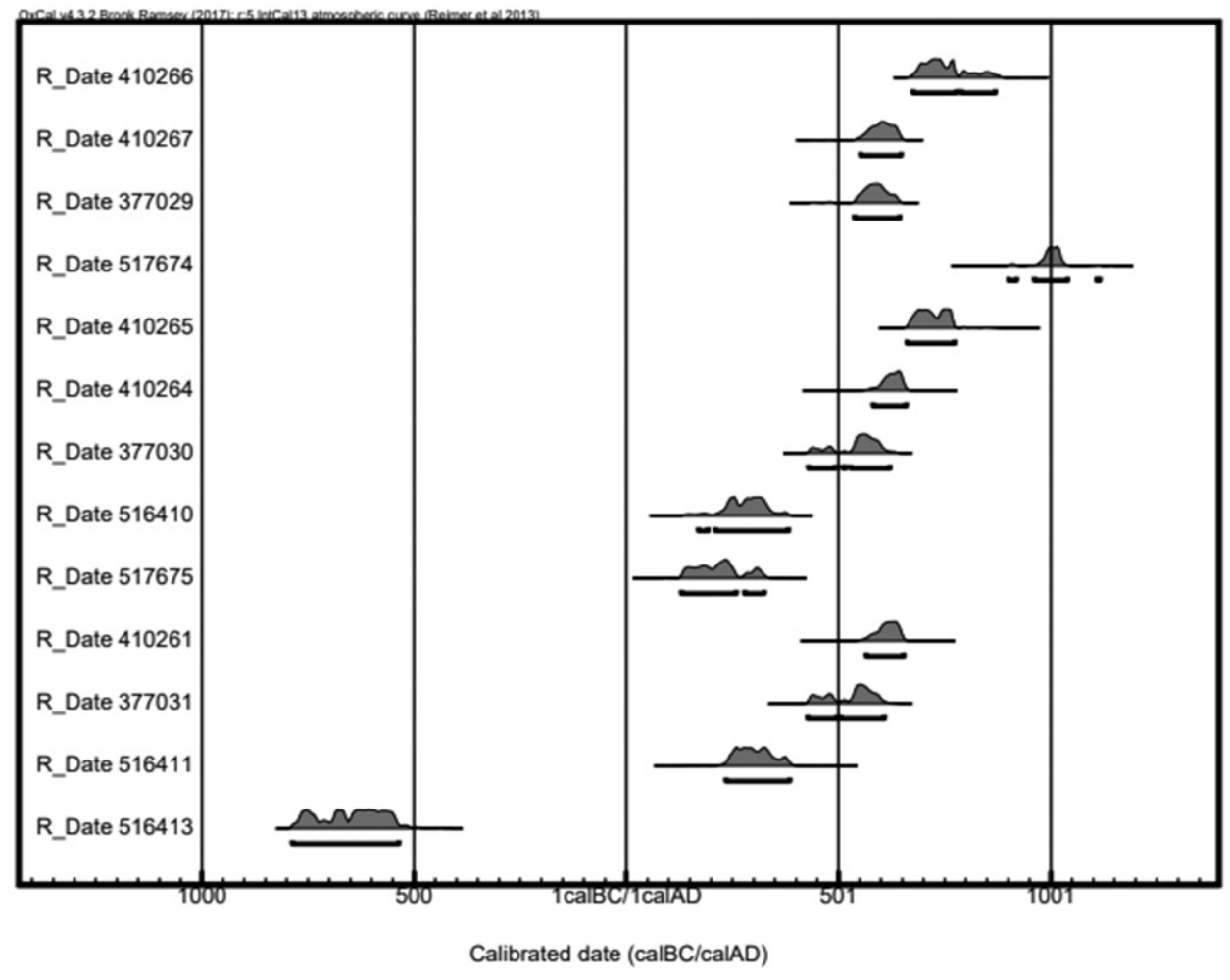

Figure 1: Chronological model of site SB2H.

The significant gap raised some questions regarding the earlier period for the beginning of the site's activities. The low precision of the model outputs was due to the small number of dating results used in the analysis. Based on the multiple plots, the site SB2H could be assigned from the 2nd to 8th century AD. More ${ }^{14} \mathrm{C}$ samples, especially from the older stratigraphic layer, need to be studied to establish the earliest date for the occupation of site SB2H. For site SB2A, 18 AMS and 1 radiocarbon dates of charcoal samples taken from 11 spits were analysed (refer Appendix: Table 2). An individual sample from spit 16 (268001) was excluded from the analysis as it was far too young for its archaeological sequence (AD 1160-1240), given the other dates and stratigraphy. Based on the revised model (see Figure 2), site SB2A could be placed from the 3rd to the 7th century AD. Finally for site SB2F, 24 AMS and 5 radiocarbon dates of charcoal samples taken from 5 spits were analysed (refer Appendix: Table 3), most of which came from spit 6 (18 samples). Five dates had to be 
excluded from the analysis, as they showed poor individual agreement with other dates and their chronological sequence. Samples 298591 (50 BC-AD 70 ) and 298595 (AD 820-1010) were respectively too old and too recent as compared to the other dates coming from the same spit. As for samples 298592 (AD 248-391), 298585 (AD 430-622) and 598593 (AD 687-940), they did not seem to have an agreement with the overall model. After the five samples were excluded, the model was re-run (see Figure 3). The revised model showed that site SB2F could probably be placed between the 5th to 10th century AD.

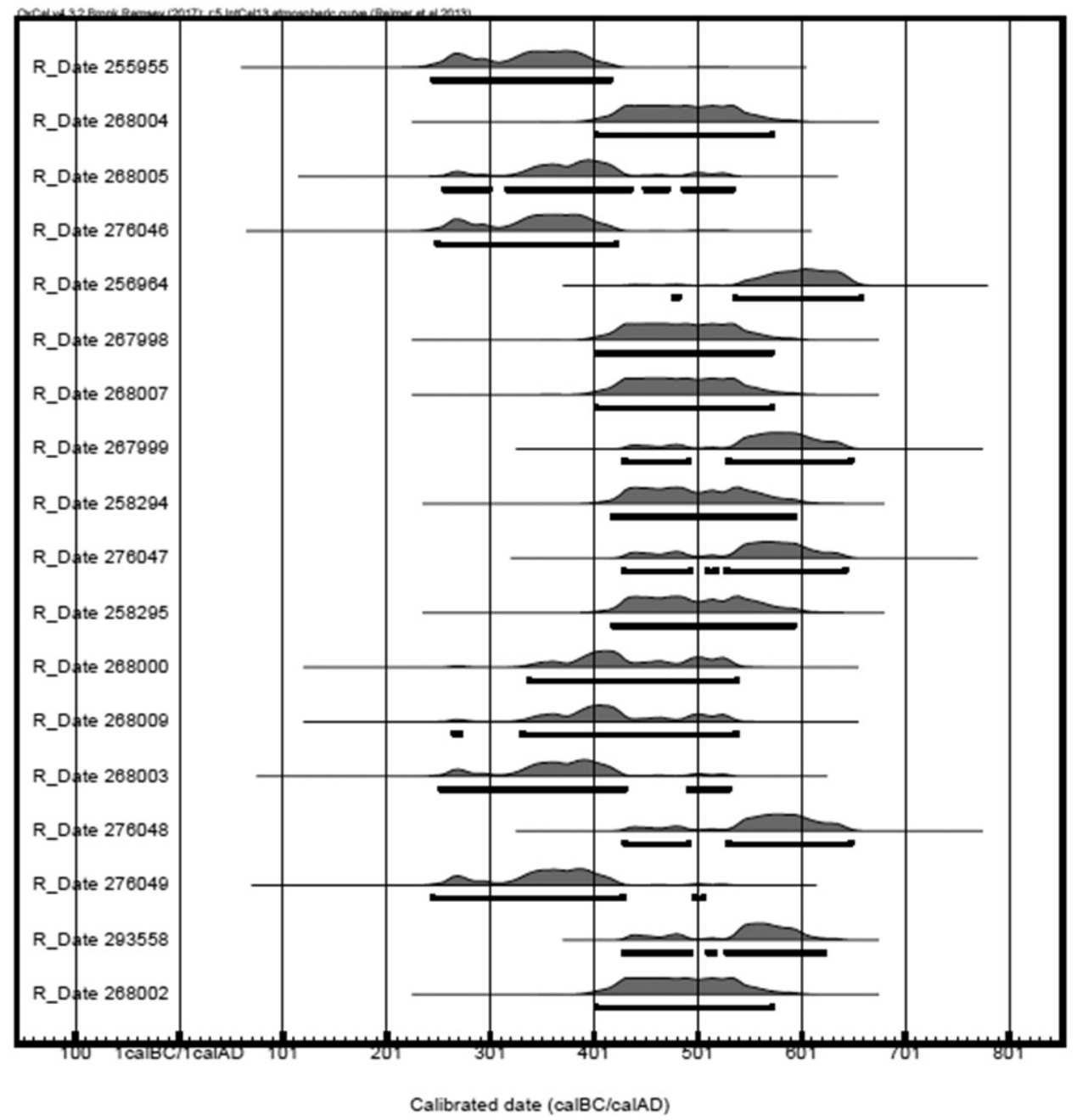

Figure 2: Chronological model of site SB2A. 


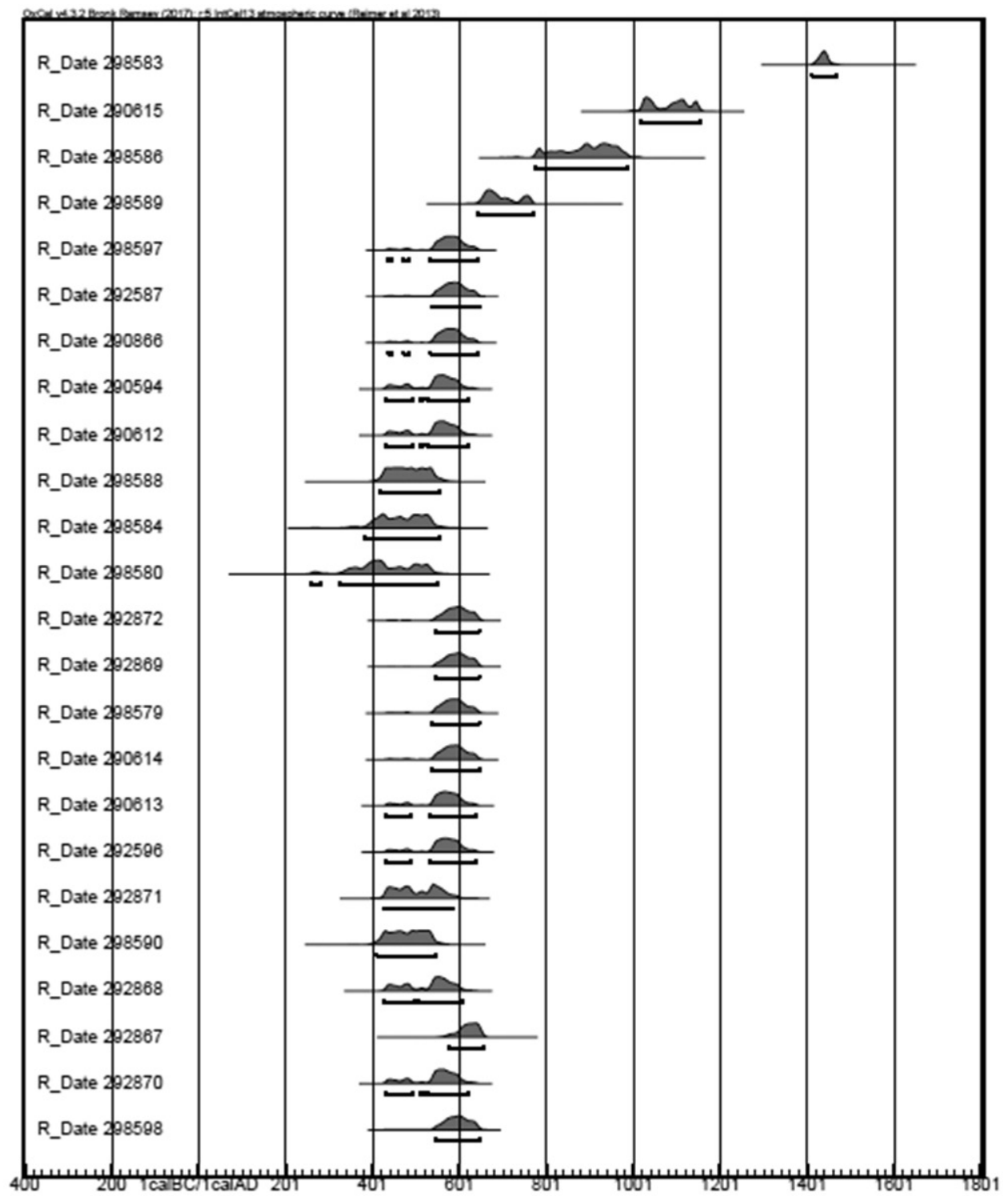

Figure 3: Chronological model of site SB2F.

The archaeological remains show that the smelting process at Sungai Batu was carried out using the bloomery method (Naizatul Akma 2012, 183; Johansen 2014, 261; Nordianah 2013, 199). The bloomery method begins with the preparation of iron ores and the construction of a furnace. The iron ores are smelted at high temperatures, producing solid spongy pieces of impure iron 
(also known as blooms) and liquid iron slag which are composed of separated gangue (Johansen 2014, 261). The melting point for iron smelting at Sungai Batu ranged from $1150^{\circ} \mathrm{C}$ to $1200^{\circ} \mathrm{C}$, while in South India (6th century $\mathrm{BC}$ sites of Guttur and Kodumanai) the melting point was between $1140^{\circ} \mathrm{C}$ to $1300^{\circ} \mathrm{C}$ (Sasisekaran 2002, 22-23). At Sungai Batu, only the bases of the furnaces were found intact, while similar finds have been reported in Mel-Siruvalur and Ban Don Phlong (Nitta 1997; Sasisekaran 2002, 25). It is believed that when the furnaces were clogged during the smelting process, they were deliberately broken to retrieve the remaining blooms (Prakash 2011, 388; Johansen 2014, 261). The blooms which were produced during the first round of smelting contain a large percentage of slag. Thus, the impurities need to be removed through the process of primary smithing to produce iron billets. The iron billets are then shaped into a finished item during secondary smithing (Johansen 2014, 261). Unfortunately, evidences for primary and secondary iron smithing have not yet been found at Sungai Batu.

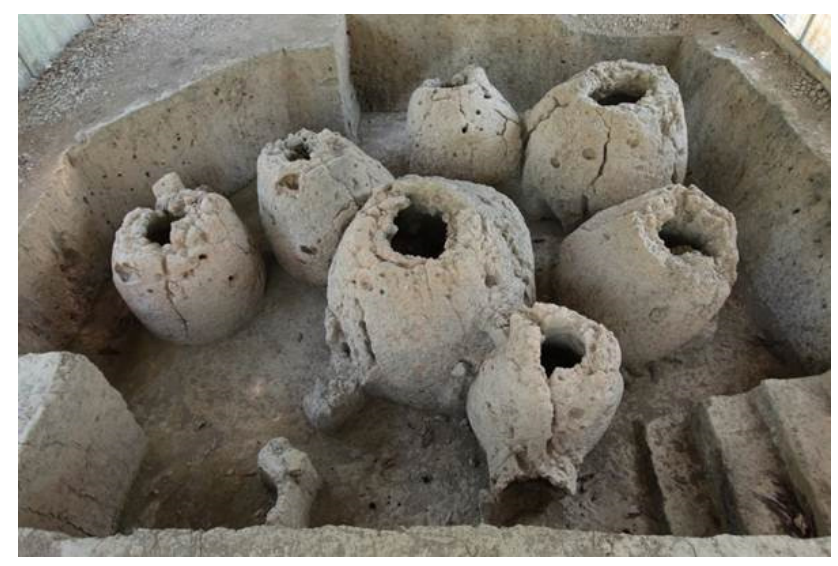

Figure 4: Intact furnaces from Jeniang.

Source: Centre for Global Archaeological Research, Universiti Sains Malaysia.

The actual shapes and sizes of the furnaces of Sungai Batu can be deduced by comparing them with the discoveries of iron smelting sites in Jeniang, located in the upper reaches of the Sungai Muda, $45 \mathrm{~km}$ from the Sungai Batu site (Farahmasrine et al. 2011) (see Figure 4). Excavations in Kampung Chemara, Kampung Sungai Perahu and Kampung Kuala Gading have uncovered a few intact and well-preserved furnaces, alongside potsherds, iron remains and a tuyere (Farahmasrine et al. 2011; Norhidayahti 2015). The dome-shaped furnaces were found clustered together. Clustered forms of furnaces have also been reported in the 6th century BC sites of Krishnagiri and Guttur in Tamil Nadu (Sasisekaran and Rao 2001; Sasisekaran 2002). The furnaces in Jeniang show 
similar characteristics with the remains found at Sungai Batu in terms of dating (1st century BC to 13 th century AD), morphology and mineralogy (Norhidayahti 2015). Comparison with the sites SB2A and SB2C suggests that the furnaces at Sungai Batu could have also been similarly dome-shaped (Naizatul Akma 2012; Nordianah 2013). Similar forms of furnaces have also been reported in Naikund, Maharashtra (dated from $700 \mathrm{BC}$ ), with conical/domed refractories attached with tuyeres which also produced semi-solid sponge iron (bloom) and liquid slag (Prakash 2011). Excavations in Ban Don Phlong revealed oblong and ovalshaped furnaces (Nitta 1997). Aside from the fragments of furnaces, a large number of artefacts directly linked to iron smelting activities, such as iron slag, iron blooms, iron ores, iron tools and tuyeres were found.

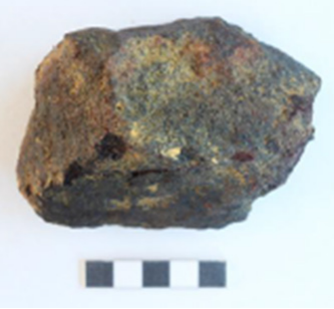

(a) Iron ore (Hematite)

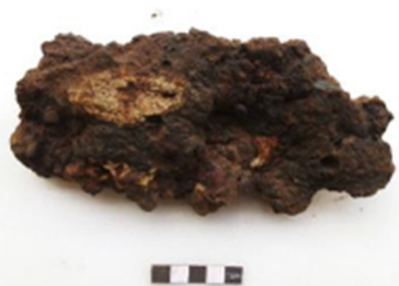

(c) Iron slag (Amorphous shaped)

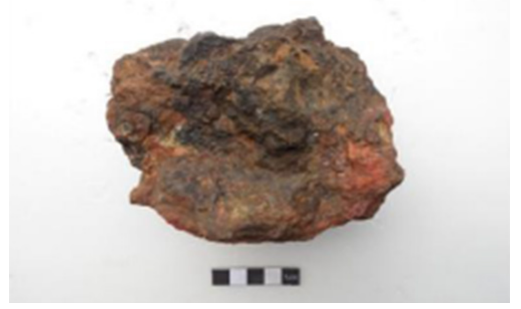

(b) Iron ore (Magnetite)

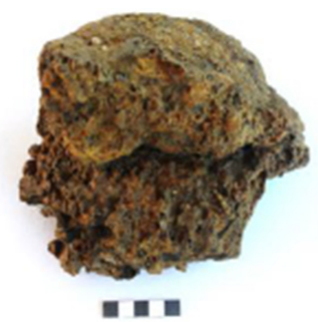

(d) Iron slag (Plano-complex shaped)

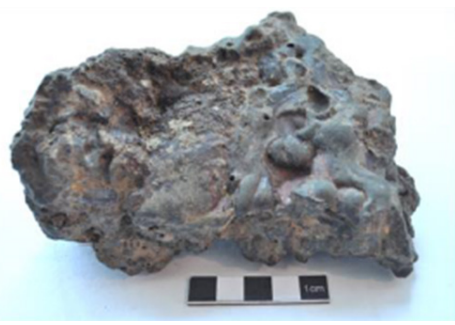

(e) Iron bloom

Figure 5: Iron ores, iron slags and iron bloom.

Source: Naizatul Akma and Mokhtar (2019). 
At sites SB2A, SB2C, SB1G, SB2F, SB1ZY and SB2H, a total of 32,676 pieces of iron ores, 56 pieces of iron blooms and 275,591 pieces of iron slag were found (Naizatul Akma and Mokhtar 2019) (see Figure 5). This indicates the scale of iron production at Sungai Batu, which existed over a significant period (Naizatul Akma 2012; 2019). Tuyeres used to regulate the temperature in the furnace, were found in large amounts at Sungai Batu. In trench P15 of site SB2A, tuyere remains can be dug up to 1.7 metres from the soil surface (see Figure 6). At site SB2A, $968.22 \mathrm{~kg}$ of tuyeres have so far been excavated and removed. All of them are regularly shaped with diameters ranging from $2.25 \mathrm{~cm}$ to $2.75 \mathrm{~cm}$ (Naizatul Akma 2012). The tuyeres appear to have been made according to certain kinds of specifications meant for mass production. Aside from findings directly related to iron smelting activities, other artefacts such as iron tools and metal ornaments were reported. Several corroded iron objects have been found in most of the iron smelting sites such as SB2A, SB2C, SB1G, SB2F and SB2H (Naizatul Akma and Mokhtar 2019) (see Figure 7). Studies on the chemical composition of the iron tools discovered at site SB2A indicate a high percentage of calcium oxide $(\mathrm{CaO})$ and sulphur trioxide $\left(\mathrm{SO}_{3}\right)$, elements which are not detected in the iron ores and iron slag found at the site (Naizatul Akma 2012). This finding could suggest that the iron tools were not locally smithed, but were brought to the site from elsewhere.

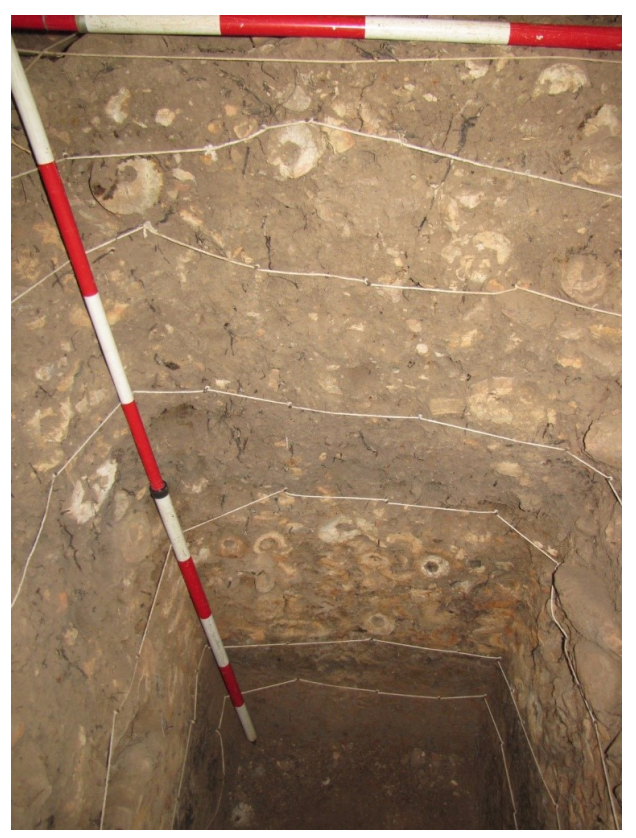

Figure 6: Tuyere remains in site SB2A (trench P15). Source: Naizatul Akma (2012). 


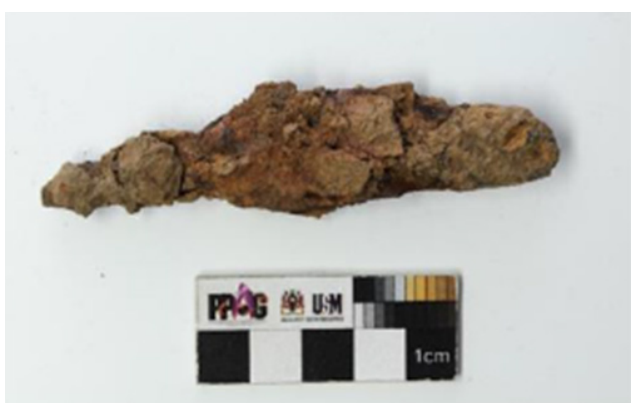

(a) Iron blade from site SB1G

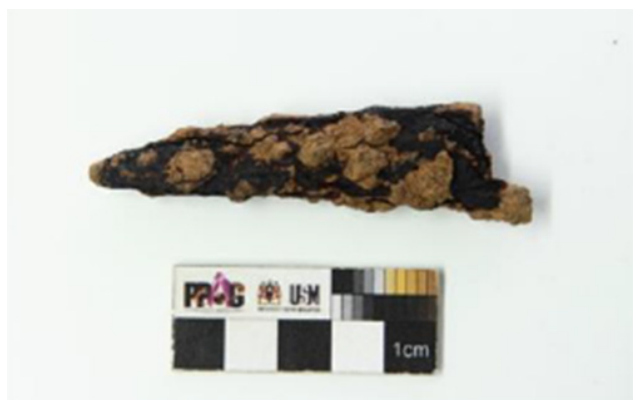

(c) Iron blade from site SB1F

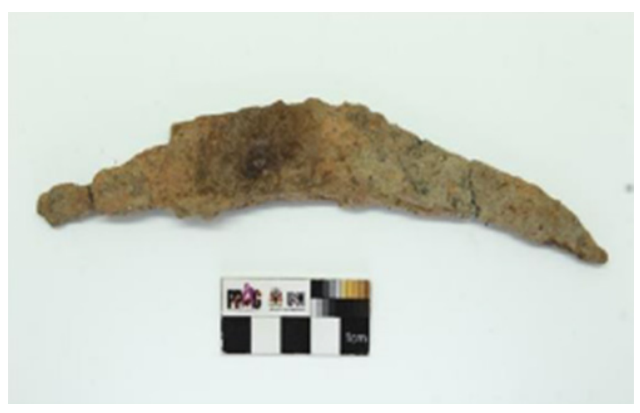

(e) Iron blade from site SB2H

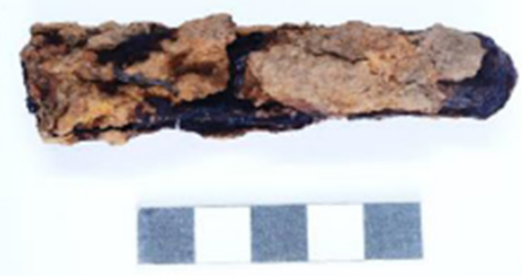

(b) Iron blade from site SB1G

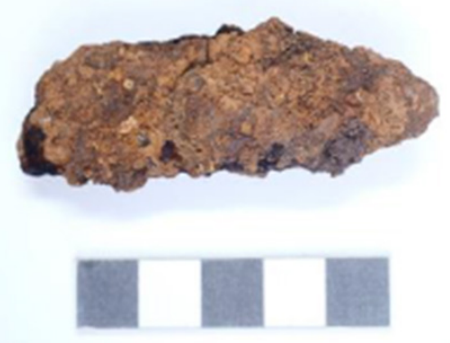

(d) Iron blade from site SB1F

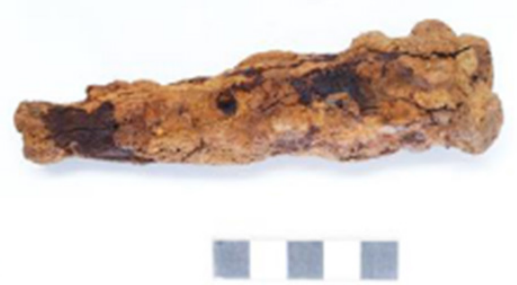

(f) Iron blade from site SB2H

Figure 7: Iron objects.

Source: Naizatul Akma and Mokhtar (2019).

Ornaments made of other kinds of metals have also been found alongside the material remains of iron smelting activities. They consisted of a bronze bangle and a metal ring (see Figure 8), both were found at site SB2A and were associated with iron slag and tuyeres (Naizatul Akma 2012). The bronze bangle, measuring $5.9 \mathrm{~cm}$ in diameter was found in trench L8 at spit 10, while the metal ring, 
measuring $2.52 \mathrm{~cm}$ in diameter was found in trench L8 at spit 6. However, the type of metal used to make the ring is still unclear as no chemical analysis has yet been carried out. The discovery of a bronze ornamental object at Sungai Batu reaffirms the opinion of Pryce (2014), who stated that during the iron age, copper and bronze were used for decorative items while more durable iron and steel were used for utilitarian objects. Similar associations of iron and bronze artefacts have been observed in South Indian iron smelting sites such as Kodumanal and Adichchanallur (Sasisekaran 2002). A large number of potsherds have been found in all of the archaeological sites excavated so far at Sungai Batu as well as in the Bujang Valley in general. Aside from the remains of iron smelting activities, they are among the most commonly found artefacts at Sungai Batu. In the iron smelting sites, they could have been used for domestic purposes such as for storing water and food (Naizatul Akma 2012; Nordianah 2013). At site SB2A, out of the 765 shards found, 759 were undecorated, while the rest had cord-marked design. At site SB2C, out of the 1,740 shards found, 1,450 were undecorated, while the rest had cord-marked and checked designs (Naizatul Akma 2012; Nordianah 2013) (see Figure 9).

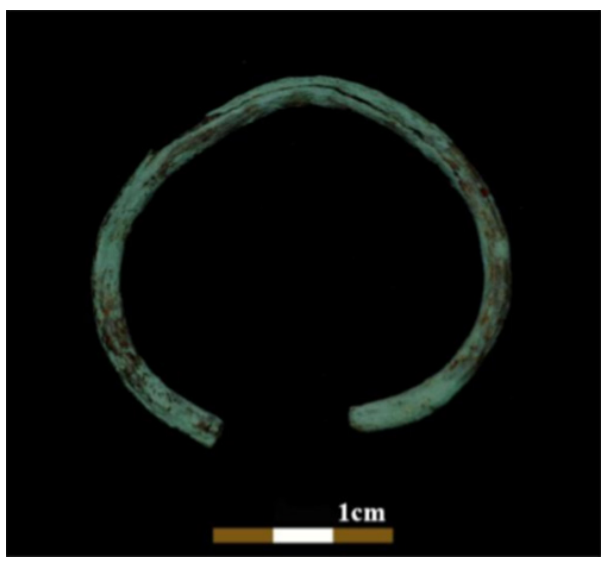

(a) Bronze bangle from site SB2A

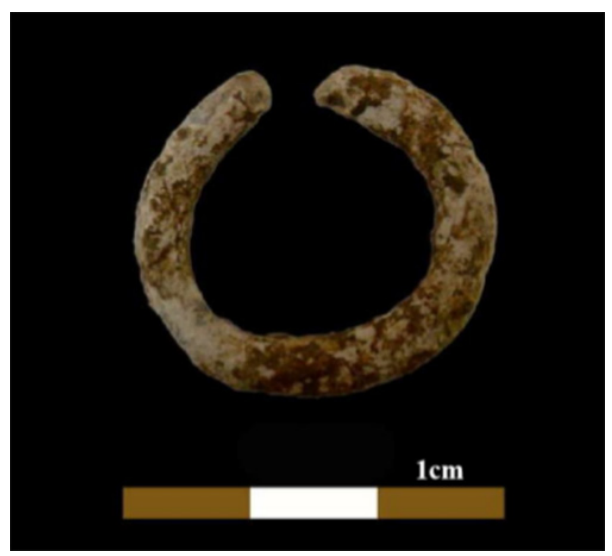

(b) Metal ring from site SB2C

Figure 8: Metal ornaments.

Source: Naizatul Akma (2012); Nordianah (2013). 


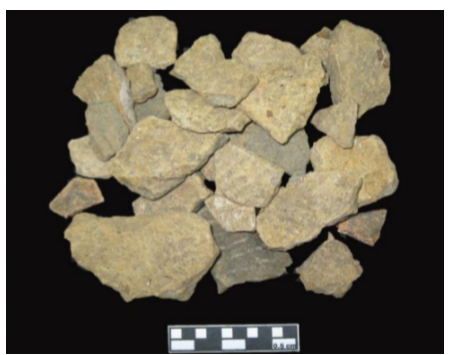

(a) Cordmarked potsherds from site SB2C

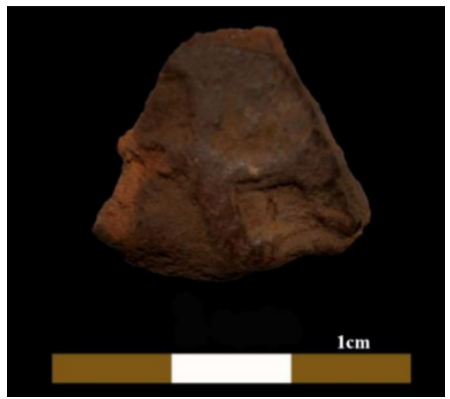

(c) Checked potsherd from site SB2A

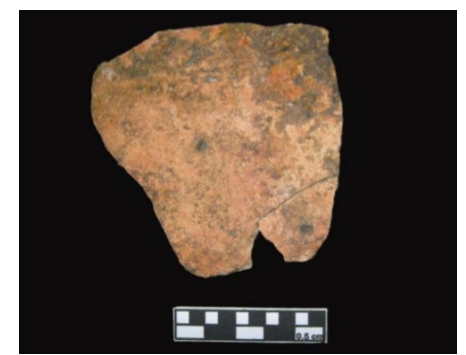

(b) Undecorated potsherd from site SB2C

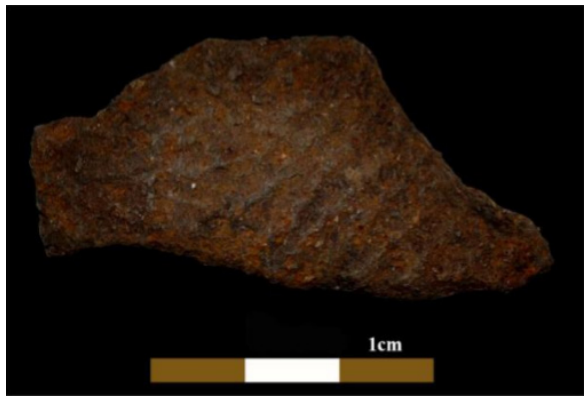

(d) Cordmarked potsherds from site SB2A

Figure 9: Potsherds.

Source: Naizatul Akma (2012); Nordianah (2013).

Artefacts related to trade such as beads and foreign ceramics have also been found. A good number of beads and fragments of trade wares have been recorded in most of the archaeological sites of Sungai Batu. Findings of beads are well documented at sites SB2B, SB2D, SB1H and SB1J (Iklil Izzati 2014; Mohd Hasfarisham 2014; 2019) (see Figure 10). A carnelian bead was found at site SB2B (trench K24, spit 5), while a monochrome glass bead was found at site SB2D (trench A19, spit 6). A terracotta bead was found at site SB1H (trench S5, spit 8) and a glass bead was found at site SB1J (trench B7, spit 3). All four of them were found just above the cultural layers. Being located near to the ancient shoreline, these materials could have easily been transported from other places and deposited onto the sites by natural elements, such as floodwater or high tide, rendering the archaeological context uncertain. Foreign ceramics dated from the 10th to 14th century AD have also been found (Naizatul Akma 2012; Siha 2014) (see Figure 11). Among those reported include the Yuan period celadon dan Sawankhalok stoneware from site SB1E (trench C11, spit 9) and Sung stoneware from site SB2A (trench T14, spit 6). All of these were found above the cultural layers (Naizatul Akma 2012; Siha 2014). The role of these ceramics 
in the iron smelting activities is still unclear, as the dating of the ceramics at site $\mathrm{SB} 2 \mathrm{~A}$ is far too recent as compared to the date of the site. Although ${ }^{14} \mathrm{C}$ dates assign site SB2A from the 3rd to the 7th century AD, the Sung stonewares are dated at 10 th to 13 th century AD.

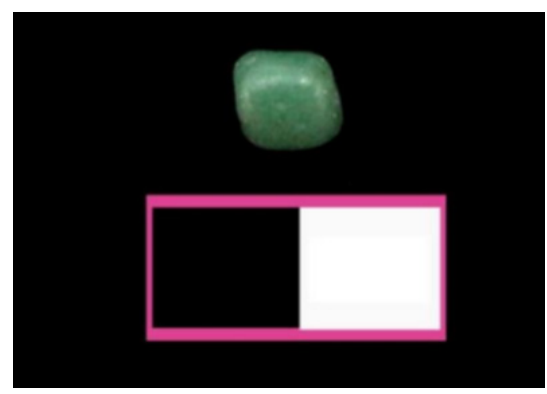

(a) Glass bead from site SB2D

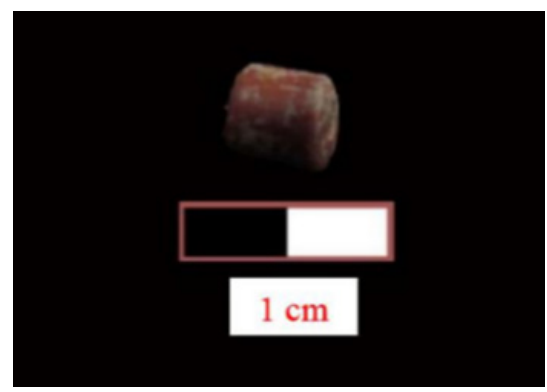

(c) Terracotta bead from site SB1H

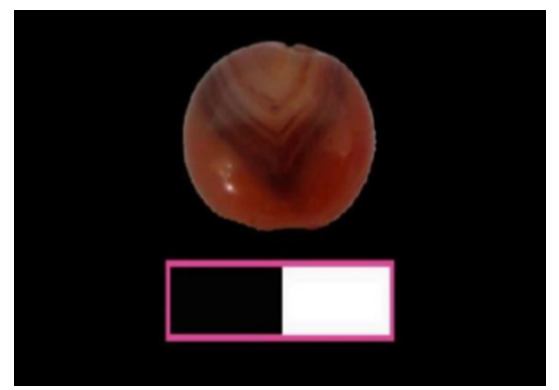

(b) Carnelian bead from site SB2B

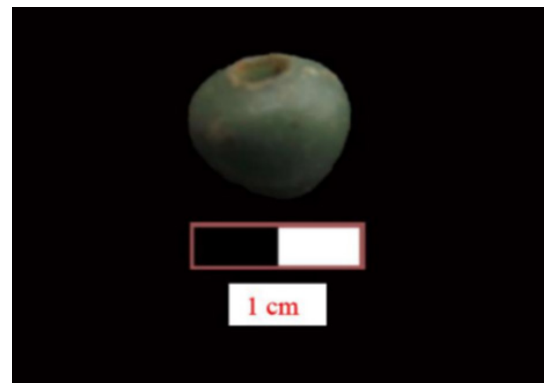

(d) Glass bead from site SB1J

Figure 10: Beads.

Source: Iklil Izzati (2014); Mohd Hasfarisham (2014).

Aside from the iron smelting sites, excavation at Sungai Batu has also revealed extensive ruins made of bricks. These structural remains consisted of floorings, walls, stairs, corridors, as well as what appears to be cylindrical-shaped structures (possibly bollards), which are almost entirely made of bricks. Material remains such as iron tools, potsherds, beads, food remains, stone bobbins and even a fragment of a terracotta figurine have been reported at the sites (Iklil Izzati 2014; Nurashiken 2016; Mohd Hasfarisham 2019). Parallel finds of jetties can be observed in several ancient ports, such as Dwarka and Porbandar (Gaur, Sundaresh and Odedra 2004; Gaur, Sundaresh and Tripati 2004; 2006). Studies suggested that most of these brick structures could have functioned as wharves for the loading and unloading of vessels. The discoveries of roof tiles (see Figure 12) and traces of pillar bases (see Figure 13) show that these structures 
were most probably roofed. Built on the ancient river banks, the floors had small channels between regular intervals of brick pavements, probably to drain out water during high tide (Mohd Hasfarisham 2014; Iklil Izzati 2014) (see Figure 14). The walls which were possibly the outermost limit of the wharf were usually found between 4 to 10 layers of bricks (see Figure 15). The presence of stairs (Iklil Izzati 2014) and paved corridors (Mohd Hasfarisham 2014) were suggested to have functioned as pathways leading from the riverbank to the land. To date, direct archaeological evidence which could confirm the relationship between the major iron smelting sites and the brick structures has not yet been found. However, the association can be suggested based on the sites' overall layout and orientations, observable from the site plans superimposed onto the reconstructed ancient coastline of the area (see Figure 16).

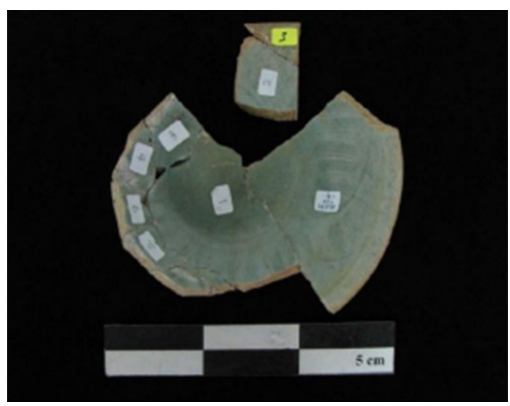

(a) 14th century Sawankhalok ceramic from site SB1E

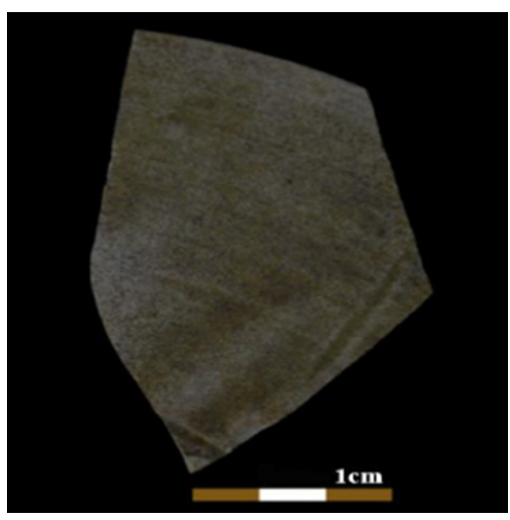

(c) 10th-13th century Sung ceramic from site SB2A

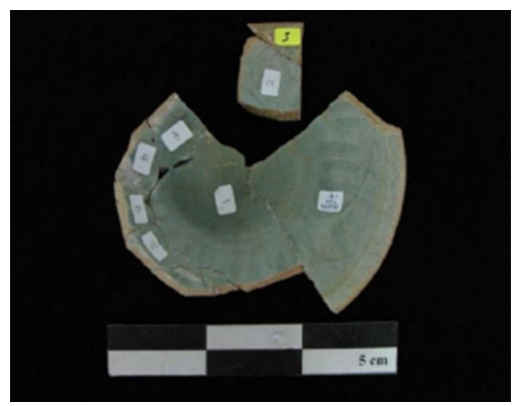

(b) 13 th/14th century Yuan ceramic from site SB1E

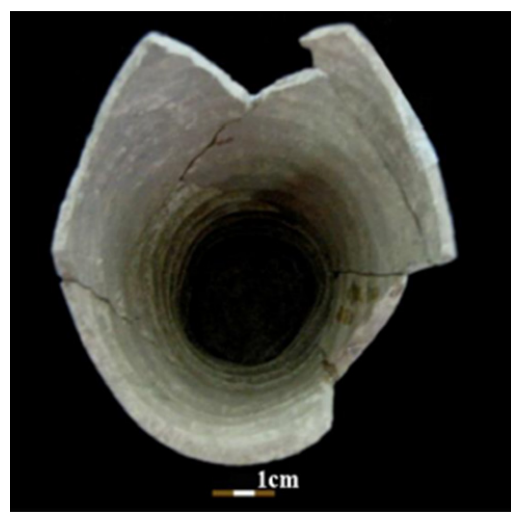

(d) 10th-13th century Sung ceramic from site SB2A

Figure 11: Foreign ceramics. Source: Naizatul Akma (2012); Siha (2014). 


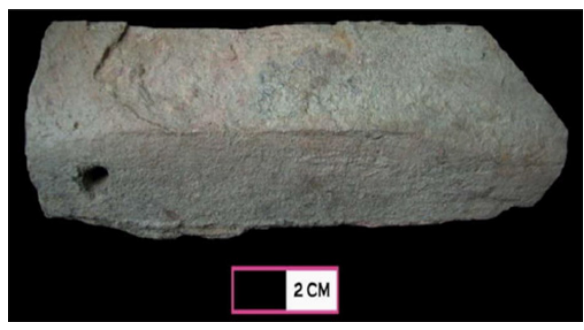

(a) Pointed shaped rooftile

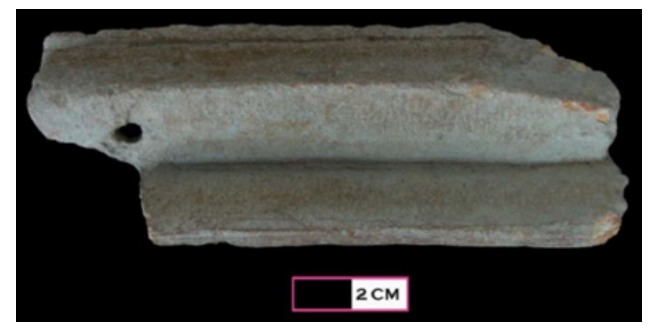

(b) Zigzag shaped rooftile

Figure 12: Rooftiles.

Source: Iklil Izzati (2014).

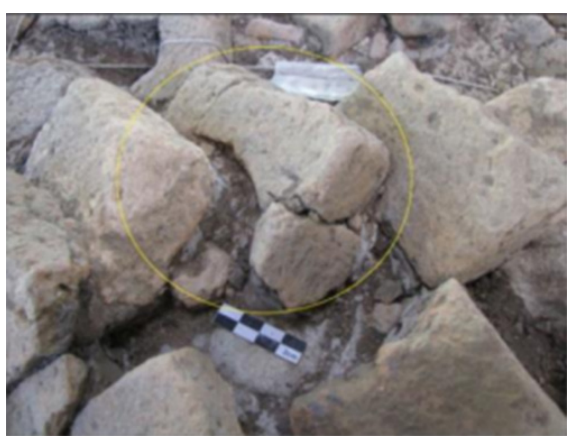

(a) Pillar base in site SB2B

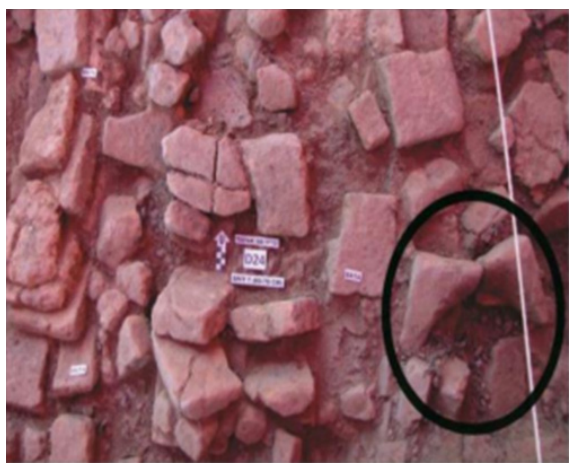

(c) Pillar base in site SB1Y

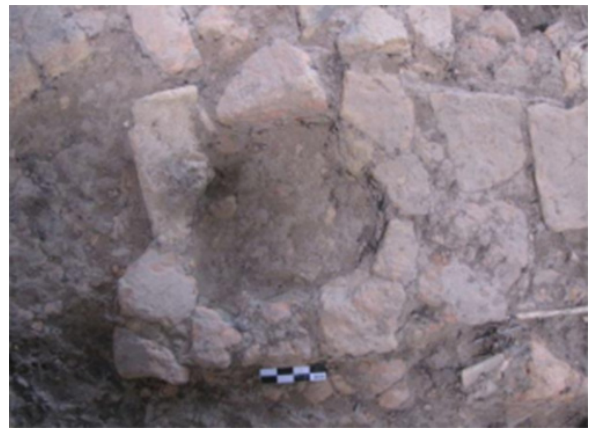

(b) Pillar base in site SB2D

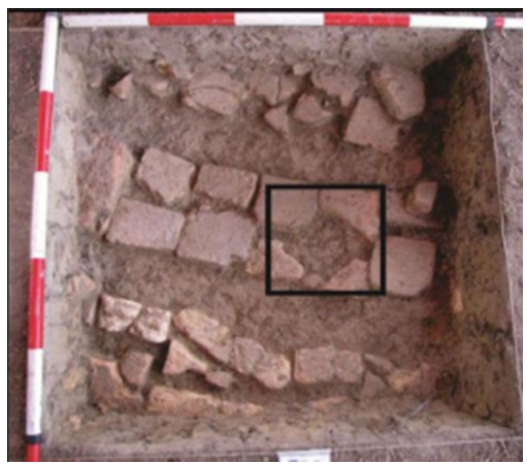

(d) Pillar base in site SB1L

Figure 13: Pillar bases.

Source: Iklil Izzati (2014); Mohd Hasfarisham (2019). 


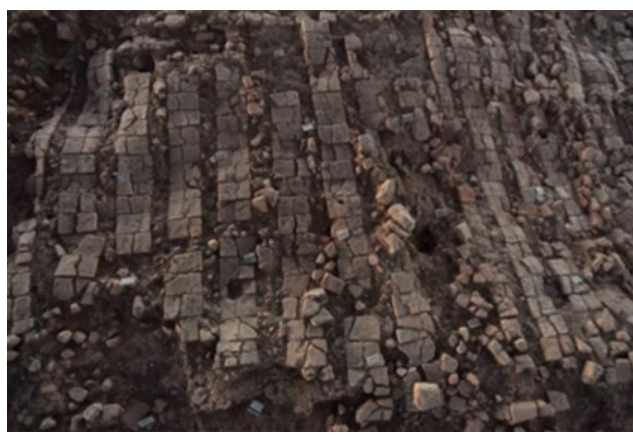

(a) Floor remains in site SB1A

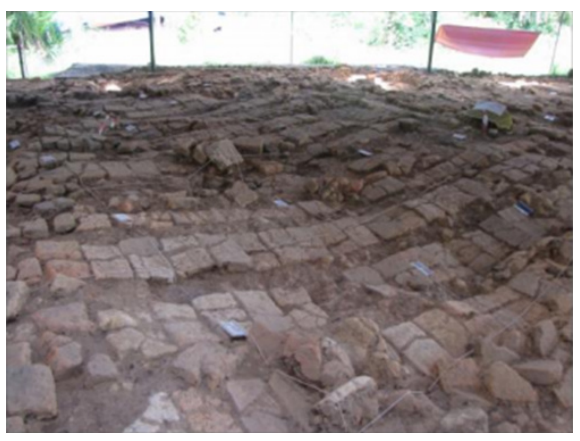

(b) Floor remains in site SB2D

Figure 14: Floor remains.

Source: Zolkarnian, Chia and Hamid (2009); Iklil Izzati (2014).

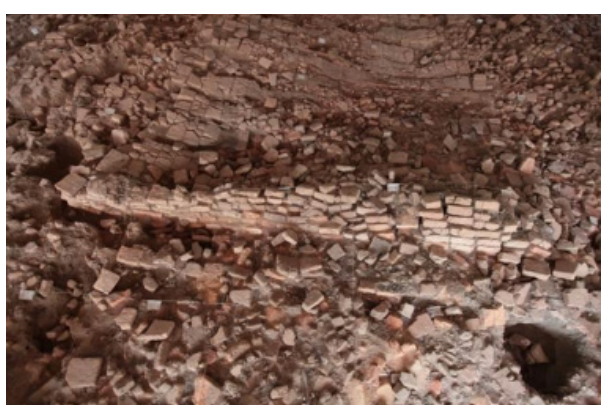

(a) Wall remains in site $\mathrm{SB} 1 \mathrm{~A}$

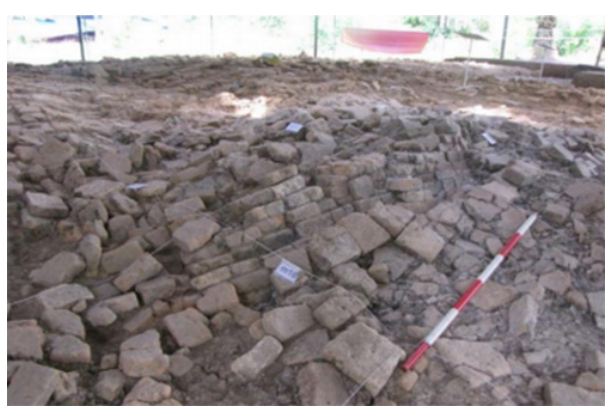

(b) Wall remains in site SB2D

Figure 15: Wall remains.

Source: Zolkarnian, Chia and Hamid (2009); Iklil Izzati (2014).

Although the structural remains of these wharf sites are in an extremely ruined state, the palaeo-environmental study and 3D conjectural reconstructions have provided some insights into their roles (Iklil Izzati 2014; Mohd Hasfarisham 2019). Palaeo-environmental reconstruction has shown that Sungai Batu was located at the coastline of a sheltered bay, a suitable natural feature for the construction of wharves (Gaur and Vora 2007). The brick structures appear to have possessed the structural characteristics outlined by De Kerchove (1948), which is "the engineering structures projecting into the water of a nature of a pier, dike, embankment, constructed of timber, earth, stone or a combination thereof". The brick structures, such as at sites SB1B, SB1D, SB1Y and SB1A appear to have been located to the west of the iron-smelting sites of sites SB2H, SB1F, SB1G and SB1ZY (see Figure 16). These brick structures were all built along the ancient shoreline, projecting into the inlet. They seem to be strategically 
positioned adjacent to the iron smelting sites, separated by no more than $150 \mathrm{~m}$ in distance. The detailed chronology for sites SB1B, SB1D, SB1Y and SB1A cannot yet be established due to the small number of ${ }^{14} \mathrm{C}$ and optically stimulated luminescence (OSL) dates available (refer Appendix: Table 5). Nevertheless, the dates suggest that the periods of occupation of the wharf sites were at least partially contemporary with the iron smelting sites of SB2H, SB2A, SB1F, SB1G and SB1ZY. The presence of these non-religious structures in the Sungai Batu Archaeological Complex and not in other Ancient Kedah sites was probably due to necessity. The main produce of this complex appears to have been iron blooms which had been discovered at the wharf sites near to the ancient coastline, especially at site SB2D (Mohd Hasfarisham 2019, 265). There was probably a need for strong wharf structures to bear the weight of the considerably heavy materials without collapsing.

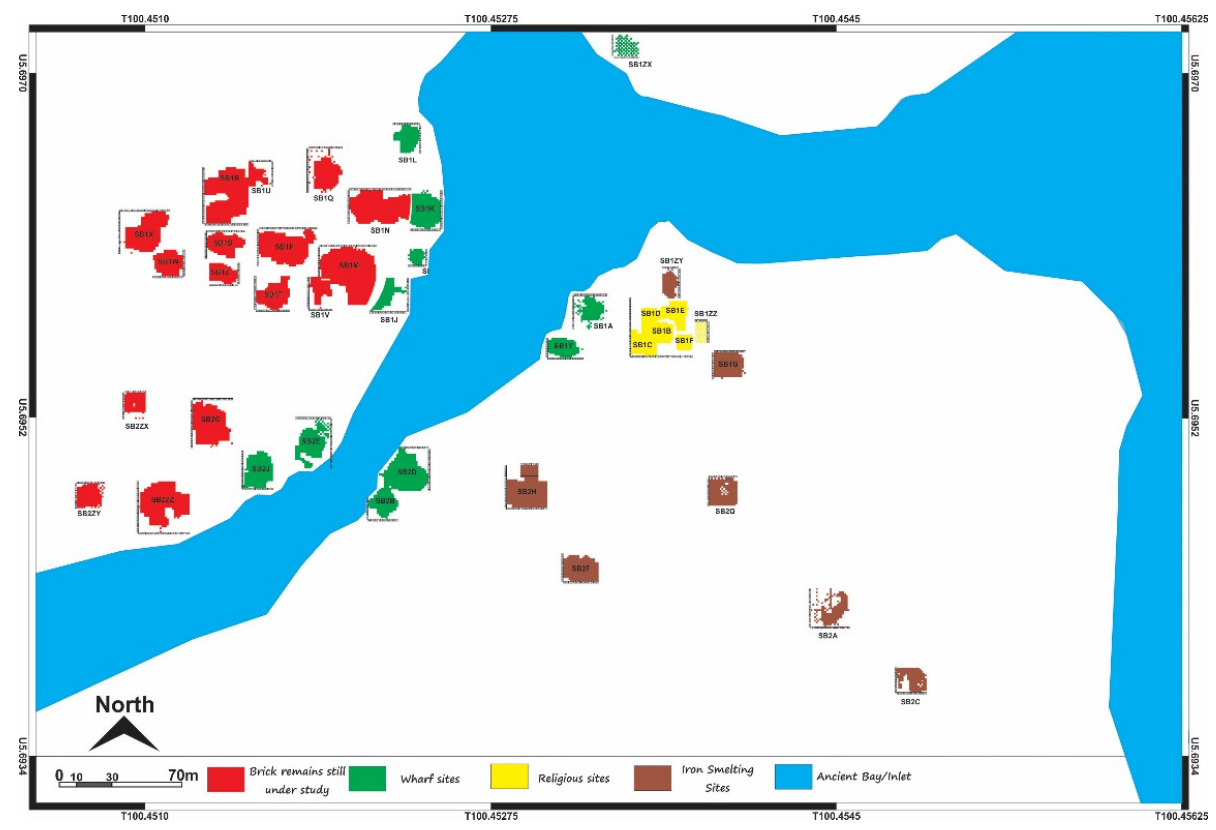

Figure 16: Sungai Batu Complex layout with reconstructed Ancient Coastline.

Despite Sungai Batu's role as a site for iron smelting activities, the area was not entirely devoid of spirituality as a religious site was also discovered, known as site SB1B (Zolkarnian, Chia and Hamid 2011). The excavation unearthed big piles of broken bricks which appear to be the remains of the collapsed upper structure of a building. After the bricks were carefully recorded and removed, a structure with an interesting architectural design was unveiled. It consisted of three main elements which were a circular brick floor (diameter $10.17 \mathrm{~m}$ ), 
a square brick structure $(5.91 \mathrm{~m} \times 5.91 \mathrm{~m})$ above the circular floor and a cylindrical void $(3.12 \mathrm{~m}$ ) in the middle of the square structure (Zolkarnian, Chia and Hamid 2011). The total height of what remains of this monument is only $1.2 \mathrm{~m}$. The shape of this monument shows a close resemblance with other early Buddhist stupas. However, it is difficult to determine the date on an architectural basis, as only the substructure is preserved. Excavation on the surrounding area of site SB1B unveiled the ruins of the extension of the site, which could have functioned as living quarters or a worshipping hall (Siti Nurul Siha 2014). During the excavation at site SB1B and the surrounding area, broken potteries and inscriptions were also uncovered (Zolkarnian, Chia and Hamid 2011). Two inscriptions were found, a stone inscribed epigraph containing Sagaramatimariprccha text ${ }^{1}$ while the other was a fragmentary Ye Te Mantra inscribed on a gold leaf. Both were written in the Southern Indian Pallava script and palaeographically placed at $7 \mathrm{th} / 8$ th century $\mathrm{AD}$, which shows some similar characteristics with the 7 th/8th century inscriptions from Burma, Thailand and Southern India (Dani 1986). Similar Sagaramatimariprccha inscriptions were also reported from Kampung Pendiat and Kampung Sungai Mas, which have also been associated with Buddhist stupas (Wales 1940; Nasha 2011).

\section{DISCUSSIONS}

Metalworking industry played a pivotal role in the cultural, economic and sociotechnological development of polities in Southeast Asia. According to Higham, Higham and Kijngam (2011), the earliest evidence of copper-based metallurgy in mainland Southeast Asia can be dated from the end of the 2nd millennium BC. The technology was believed to have been derived from contacts with the population of China (Pryce et al. 2011). However, in the insular Southeast Asia, copper-based and other precious metal metallurgies appeared only after the mid-first millenium $\mathrm{BC}$, synchronous with the appearance of iron metallurgy both in the mainland and insular zones (Bellwood 2007). According to Biggs et al. (2013), there were three possibilities for the origin of iron metallurgy in Southeast Asia which were (1) Indian origin of the bloomery and crucible steel technologies; (2) Chinese origin of the bloomery and cast-iron technology; or (3) Local innovation from the established continental Southeast Asia copper-based technology. In the Thai-Malay Peninsula, iron smithing sites dated from the 4th to the 3rd century BC have been reported at the sites of Khao Sam Khaeo, Khao Sek and Phu Khao Thong (Bellina et al. 2014; Bellina 2016; 2018; Petchey et al. 2018). These smithing sites almost exclusively used iron blooms which were produced elsewhere using the bloomery method, a technique with strong links with South Asia (Biggs et al. 2013; Bellina 2018). 
The presence of iron smelting sites in Southeast Asia has not been well recorded. So far, only three have been reported, which are Sungai Batu (Kedah, Malaysia), Ban Don Phlong (Northeastern Thailand) and Sriksetra (Central Myanmar) (Petchey et al. 2018). Sungai Batu provides the first evidence of early historic primary iron production in insular Southeast Asia, which involved the activities of iron mining and smelting to produce raw iron blooms. The overall chronology of the Sungai Batu iron smelting complex has not yet been finalised as there are still many undated sites. The present Bayesian chronological model has given rough estimates of the chronology for site SB2H (2nd to 8th century AD), site SB2A (3rd to 7th century AD) and site SB2F (5th to 10th century AD). While many of the sites remain unexcavated, current data suggests an extensive complex of iron smelting industry using the bloomery method. Similar findings in Sriksetra and Ban Don Phlong have been dated earlier than Sungai Batu. Excavation of the Tabet-Ywa iron smelting site located in Sriksetra unveiled a mound of iron slag which was $2 \mathrm{~m}$ deep and covered an area of $14,000 \mathrm{~m}^{2}$, dated from the 1 st to the 3rd century AD (Hudson 2012). The iron blooms were produced by burning a mixture of charcoal and haematite in furnaces, and they were probably forged into nails and other hardware (Hudson 2012). In northeastern Thailand, the remains of iron smelting activities in Ban Don Phlong consisted of 17 ellipsoidal and oval furnaces, tuyeres, as well as a large amount of iron slag and potsherds (Nitta 1997). The 12 radiocarbon dates assign the site from the 3rd to the 1 st century $\mathrm{BC}$, mainly concentrated in the 2nd century BC (Nitta 1997).

The preliminary dating has shown that the iron mining and smelting activities at Sungai Batu began in the 2nd century AD, after the decline of Khao Sam Kaeo, Ban Don Phlong and Sriksetra (Nitta 1997; Hudson 2012; Bellina and Silapanth 2006). Being located in the Bujang Valley, Sungai Batu was probably one of the polities within Ancient Kedah with its unique economic specialisation. Historical records suggest that Ancient Kedah was already a well-known harbour for inter-regional trade by the 2nd century AD, especially for the South Indians. The development of Ancient Kedah at the beginning of the 1st millenium AD is attested by Tamil literary accounts from the Sanggam age, a historical period of Southern India between the 3rd century BC to the 4th century AD (Nilakantha 1975, 30). The strategic location of Ancient Kedah which is conveniently situated across the Bay of Bengal from the Coromandel Coast had given the port easy access to South Indian trade. The earliest sources known to have mentioned Ancient Kedah are Pattinappalai and Sillappadikaram, two Tamil literary sources which can be dated around 2nd century AD. In one of the poems of Pattinappalai, a verse mentions that "goods from Kazhagam" were traded in the port of Kaveripattinam (Nilakantha 1975, 82; 
Zvelebil 1973, 57; Braddell 1989, 346-347). ${ }^{2}$ Another source is the 14th century AD commentary of the Epic Sillappadikaram, mentioning that a variety of agarwood known as Kidaravan could be found in the city of Madurai. Kidaravan could have referred to Ancient Kedah (Braddell 1989). These records suggest that, at least since the 2nd century AD, Ancient Kedah had already established close trade relations with the ports of South India. Aside from spices and rainforest products, the goods from Kazhagam, as mentioned in Pattinappalai, may have included raw iron produced at Sungai Batu.

Since the 4th century BC, there have been settlements of foreigners who lived in the sites of Khao Sam Kaeo, Khao Sek and Phu Khao Thong, consisting of traders, craftsmen and artisans coming from South Asia, China and Southeast Asia (Biggs et al. 2013). The foreign craftsmen and artisans were actively involved in local industries, who adapted their production techniques to fulfil Southeast Asian demands (Pryce et al. 2010). Similar phenomenon may also have been possible in Ancient Kedah which possessed all of the natural advantages for its development as a port-industry. Ancient Kedah had protected bays and inlets suitable for trading vessels to harbour, an abundance of raw materials, such as tin and iron ore, supplies of fresh water, as well as rich hinterlands connected to the coastline by riverine networks (Nasha 2011). Ancient Kedah's geostrategic location just across the Bay of Bengal from the Coromandel Coast made it a convenient stopover for mariners sailing to or from the Straits of Malacca. The beginning of the 2 nd century AD also marked a phase in the development of the Indian-Southeast Asian exchange link when inter and intraregional trade intensified with the rise of local industries and manufacturing (Bellina and Glover 2004). This period was also characterised by less diversity and a greater quantity of the items produced (Bellina and Glover 2004). This can be observed from the comparison between the findings in Khao Sam Kaeo and the Bujang Valley. Between the 4th and 2nd century BC, local industries of diverse products flourished in Khao Sam Kaeo, such as glass, agate, carnelian and nephrite ornaments, copper-based items, iron tools, as well as Western Han, Sa Huyn Kalanay and Rouletted potteries (Bellina and Silapanth 2006; Bellina et al. 2014). However, for the post-2nd/3rd century CE Bujang Valley, only the remains of iron smelting at Sungai Batu and a glass bead industry at Kampung Sungai Mas have been found, though in a considerably larger scale (Zuliskandar, Nik Hassan Shuhaimi, Adnan et al. 2014; Naizatul Akma 2012; 2019). 


\section{CONCLUSION}

The excavation and chronometric dating of the Sungai Batu sites have so far uncovered several iron smelting workshops dated from the $2 \mathrm{nd} / 3 \mathrm{rd}$ century AD, employing the direct/bloomery method. Similar finds of the direct method of iron smelting activities have been reported in other Southeast Asian sites, such as Ban Don Phlong (3rd to 1st century BC) and Sriksetra (1st to 3rd century AD), while numerous more have been found in South India. Although circumstantial evidence has pointed out the likelihood of the South Asian origin of the smelting technique used at Sungai Batu, whether the smelting activity was done by South Asian smelters or South Asian trained local smelters has yet to be proven. The discoveries of brick structures along the ancient coastline and adjacent to the iron smelting sites can suggest their role as wharves to load the iron blooms into waterborne vessels. Findings at the Sungai Batu Archaeological Complex have positioned Ancient Kedah as another port-industry which flourished owing to its geostrategic position and natural resources, as well as the transfer of culture and technology resulting from trans-Asiatic trade which began in the late centuries BC. In the 2nd century AD, Ancient Kedah was already well-known, at least among South Indian traders. As a port-industry, Ancient Kedah probably established trade relations with cities like Madurai and Kavetipattinam.

Aside from iron, other commodities which were in high demand such as beads, rainforest products and spices were also most likely traded in Ancient Kedah. The emergence of Ancient Kedah in the $2 \mathrm{nd} / 3$ rd century AD was probably the direct result of the intensifying Indian-Southeast Asian exchange link. From the 7th century AD onwards, different economic hubs outside of Sungai Batu, such as Pengkalan Bujang and Kampung Sungai Mas continued to attract more traders from the Middle East, China and South Asia, leading to their growth as emporiums. Although Ancient Kedah is generally described in various historical accounts as a single political and port entity, its internal organisation possibly consisted of several confederated settlements with their economic specialisations. These settlements included Sungai Batu, Kampung Pengkalan Bujang and Kampung Sungai Mas. The presence of several nodes for exchange sites and industries in Ancient Kedah is comparable with the earlier network of industrial and exchange sites of Khao Sam Kaeo, Khao Sek, Phu Khao Tong and Bang Kluay Nok. Despite the abundance of archaeological findings, the lack of epigraphic evidence poses some problems in getting a definitive answer on how the settlements of Ancient Kedah were organised and administered.

Interpretations regarding the culture and socio-technology of Sungai Batu are not yet conclusive because a large area of the archaeological complex has not 
yet been excavated, while evidence of primary and secondary smithing sites for the blooms have not yet been found. Systematic sampling for ${ }^{14} \mathrm{C}$ dating using the Bayesian chronological model is still needed to establish detailed chronological phases and cultural sequence of the sites. Nevertheless, the present study suggests that the emergence of Ancient Kedah as a port-industry was the result of the trans-Asiatic trade. This had likely led to the gradual cultural exchange and the transfer of technology, and subsequently, the growth of the iron smelting industry at Sungai Batu. Other economic hubs, such as Kampung Sungai Mas and Kampung Pengkalan Bujang probably developed simultaneously with Sungai Batu in the successive centuries, which collectively transformed Ancient Kedah into a regional entrepôt.

\section{ACKNOWLEDGEMENTS}

We greatly acknowledge the Ministry of Higher Education Malaysia for granting the Fundamental Research Grant Scheme (FRGS) entitled "The Archaeological Monument of Bukit Choras: Geo-Archaeological Survey and Geophysical Mapping" (FRGS/1/2017/SSI05/USM/03/1) which funded and supported the research and writing for this paper. The Research University Top Down Grant entitled "Kajian Arkeologi Sungai Batu: Geran APEX" (1001/PARKEO/870007) had also contributed in this research. We would like to thank Mr. Shaiful Idzwan Shahidan, Dr. Goh Hsiao Mei, Dr. Felice Noelle Rodriguez, Dr. Neil Khor Jin Keong, Ms. Nini Havela Dishong, Mrs. Iklil Izzati Zakaria, Mrs. Siti Nurul Siha Mohamad and Mr. Irfanullah for their assistance, constructive and valuable comments which have improved the manuscript's quality. Finally, we would like to thank the National Heritage Department and the Malaysian Museums Department, for the all the assistance afforded to us throughout our research.

\section{NOTES}

1. Following are the translation and transliteration (Zolkarnian, Chia and Hamid 2011; Skilling 2018):

balāni daśa catvāri vaiśāradyāni yāni ca aștādaśa ca buddhānām dharmmā āvenikā hi ye ye pratītyasamutpannā na te kecit svabhāvatah ye svabhāvā na vidyante na teșām sambhavah kvacit jānīte ya imām koțìn akoțìn jagatas samām tasya koțīn gatam jñānam sarvadharmeșu varttate 
The ten types of powers, the four kinds of confidence

And the eighteen qualities, that are unique to Buddhas

Those things that have arisen in dependence

[Have not arisen] from any own nature [of their own accord]

Those that do not exist from [their] own nature [of their own accord]

For them there is no arising. One who knows that this limit

Of the world is equal to no limit: His wisdom has gone to the limit

And functions with regard to all dharmas.

2. The text runs as following (Nilakantha 1975, 83):

Under the guardianship of the gods of enduring glory, horses with a noble gait had come by the sea; bagfuls of black pepper had been brought in carts; gems and gold born of the northern mountain, the sandal and agil from the western mountain, the pearl of the southern sea, the coral of the western sea, the products of the Ganges (valley), the yield of the Kaveri, foodstuff from Ceylon, and goods from Kāzhagam, all these materials, precious and bulky alike, were heaped together in the broad streets overflowing with their riches (Pattinappalai). 


\section{APPENDIX}

Table 1: AMS dates of site SB2H

\begin{tabular}{|c|c|c|c|c|c|}
\hline Beta & Trench & Method/sample & $\begin{array}{c}\text { Conventional } \\
\text { date }\end{array}$ & $\begin{array}{l}\text { Calibrated } \\
\text { date }\end{array}$ & Artifact association \\
\hline \multicolumn{6}{|c|}{ SPIT 8} \\
\hline 516412 & N3 & AMS/charcoal & $1000 \pm 30 \mathrm{BP}$ & AD 983-1152 & Tuyere fragments and iron slag \\
\hline \multicolumn{6}{|c|}{ SPIT 7} \\
\hline 516413 & D4 & AMS/charcoal & $2500 \pm 30 \mathrm{BP}$ & $788-537 \mathrm{BC}$ & $\begin{array}{l}\text { Tuyere fragments, iron ores } \\
\text { and iron slag }\end{array}$ \\
\hline 516411 & Y17 & AMS/charcoal & $1740 \pm 30 \mathrm{BP}$ & AD 236-386 & $\begin{array}{l}\text { Tuyere fragments, iron ores, } \\
\text { laterite and iron slag }\end{array}$ \\
\hline 377031 & Q11 & AMS/charcoal & $1520 \pm 30 \mathrm{BP}$ & AD 428-609 & $\begin{array}{l}\text { Tuyere fragments, iron slag } \\
\text { and iron ores }\end{array}$ \\
\hline 410261 & F12 & AMS/charcoal & $1440 \pm 30 \mathrm{BP}$ & AD 566-655 & Tuyere fragments and iron slag \\
\hline 410260 & M8 & AMS/charcoal & $590 \pm 30 \mathrm{BP}$ & AD 1299-1413 & Tuyere fragments and iron slag \\
\hline \multicolumn{6}{|c|}{ SPIT 6} \\
\hline 401263 & W14 & AMS/charcoal & $2420 \pm 30 \mathrm{BP}$ & $748-402 \mathrm{BC}$ & $\begin{array}{l}\text { Iron slag, laterite and tuyere } \\
\text { fragments }\end{array}$ \\
\hline 517675 & V14 & AMS/charcoal & $1800 \pm 30 \mathrm{BP}$ & AD 131-326 & $\begin{array}{l}\text { Tuyere fragments, laterite and } \\
\text { iron slag }\end{array}$ \\
\hline 516410 & Y17 & AMS/charcoal & $1760 \pm 30 \mathrm{BP}$ & AD 171-383 & $\begin{array}{l}\text { Tuyere fragments, iron ores, } \\
\text { laterite, iron ingots and iron } \\
\text { slag }\end{array}$ \\
\hline 517676 & $\mathrm{X} 14$ & AMS/charcoal & $870 \pm 30 \mathrm{BP}$ & AD 1045-1250 & $\begin{array}{l}\text { Tuyere fragments, laterite and } \\
\text { iron slag }\end{array}$ \\
\hline \multicolumn{6}{|c|}{ SPIT 5} \\
\hline 377030 & R9 & AMS/charcoal & $1510 \pm 30 \mathrm{BP}$ & AD 430-622 & Tuyere fragments and iron slag \\
\hline 410264 & F15 & AMS/charcoal & $1420 \pm 30 \mathrm{BP}$ & AD 582-661 & Laterite and iron slag \\
\hline 410265 & $\mathrm{C} 14$ & AMS/charcoal & $1280 \pm 30 \mathrm{BP}$ & AD $662-774$ & $\begin{array}{l}\text { Iron slag, tuyere fragments, } \\
\text { iron ores and laterite }\end{array}$ \\
\hline 517674 & W14 & AMS/charcoal & $1030 \pm 30 \mathrm{BP}$ & AD 901-1116 & $\begin{array}{l}\text { Tuyere fragments, laterite and } \\
\text { iron slag }\end{array}$ \\
\hline \multicolumn{6}{|c|}{ SPIT 4} \\
\hline 377029 & A13 & AMS/charcoal & $1480 \pm 30 \mathrm{BP}$ & AD 538-645 & Laterite and tuyere fragments \\
\hline 410267 & N8 & AMS/charcoal & $1460 \pm 30 \mathrm{BP}$ & AD 553-648 & $\begin{array}{l}\text { Iron slag, tuyere fragments, } \\
\text { bricks and laterite }\end{array}$ \\
\hline 410266 & A3 & AMS/charcoal & $1250 \pm 30 \mathrm{BP}$ & AD $676-870$ & $\begin{array}{l}\text { Bricks, iron slag, potsherds, } \\
\text { tuyere fragments and laterite }\end{array}$ \\
\hline
\end{tabular}

Source: Naizatul Akma (2019); OxCal 4.3. 
Table 2: AMS and radiocarbon dates of site SB2A

\begin{tabular}{|c|c|c|c|c|c|}
\hline Beta & Trench & Method/sample & $\begin{array}{c}\text { Conventional } \\
\text { date }\end{array}$ & $\begin{array}{l}\text { Calibrated } \\
\text { date }\end{array}$ & Artifact association \\
\hline \multicolumn{6}{|c|}{ SPIT 17} \\
\hline 268002 & M7 & AMS/charcoal & $1570 \pm 40 \mathrm{BP}$ & AD 402-572 & Clay and charcoal \\
\hline \multicolumn{6}{|c|}{ SPIT 16} \\
\hline 268001 & M7 & AMS/organic material & $860 \pm 40 \mathrm{BP}$ & AD $1045-1260$ & Clay and charcoal \\
\hline 293558 & M7 & AMS/charcoal & $1510 \pm 30 \mathrm{BP}$ & AD 430-622 & Clay and charcoal \\
\hline \multicolumn{6}{|c|}{ SPIT 15} \\
\hline 276049 & P15 & AMS/charcoal & $1680 \pm 40 \mathrm{BP}$ & AD 245-506 & Tuyere \\
\hline \multicolumn{6}{|c|}{ SPIT 13} \\
\hline 276048 & P15 & AMS/charcoal & $1490 \pm 40 \mathrm{BP}$ & AD 430-648 & Tuyere \\
\hline \multicolumn{6}{|c|}{ SPIT 12} \\
\hline 268003 & Q7 & AMS/charcoal & $1670 \pm 40 \mathrm{BP}$ & AD $252-530$ & Tuyere and iron slag \\
\hline \multicolumn{6}{|c|}{ SPIT 11} \\
\hline 268009 & S11 & AMS/charcoal & $1640 \pm 40 \mathrm{BP}$ & AD 266-538 & Tuyere and iron slag \\
\hline 268000 & $\mathrm{O} 10$ & AMS/charcoal & $1630 \pm 40 \mathrm{BP}$ & AD 338-539 & Tuyere and iron slag \\
\hline \multicolumn{6}{|c|}{ SPIT 10} \\
\hline 258295 & Q7 & AMS/charcoal & $1550 \pm 40 \mathrm{BP}$ & AD 418-594 & Tuyere and iron slag \\
\hline 276047 & P15 & AMS/charcoal & $1500 \pm 40 \mathrm{BP}$ & AD 429-643 & Tuyere and iron slag \\
\hline \multicolumn{6}{|c|}{ SPIT 9} \\
\hline 258294 & Q7 & AMS/charcoal & $1550 \pm 40 \mathrm{BP}$ & AD 418-594 & Tuyere and iron slag \\
\hline 267999 & $\mathrm{O} 10$ & AMS/charcoal & $1490 \pm 40 \mathrm{BP}$ & $\mathrm{AD} 430-648$ & Tuyere and iron slag \\
\hline \multicolumn{6}{|c|}{ SPIT 8} \\
\hline 268007 & L4 & AMS/charcoal & $1570 \pm 40 \mathrm{BP}$ & AD $402-572$ & Tuyere and iron slag \\
\hline 267998 & $\mathrm{O} 10$ & AMS/charcoal & $1570 \pm 40 \mathrm{BP}$ & $\mathrm{AD} 402-572$ & Tuyere and iron slag \\
\hline 256964 & O8 & AMS/charcoal & $1460 \pm 40 \mathrm{BP}$ & AD $478-659$ & Tuyere and iron slag \\
\hline \multicolumn{6}{|c|}{ SPIT 7} \\
\hline 276046 & P15 & Radiocarbon/charcoal & $1690 \pm 40 \mathrm{BP}$ & AD $250-422$ & Tuyere and iron slag \\
\hline 268005 & M11 & AMS/charcoal & $1660 \pm 40 \mathrm{BP}$ & AD 256-534 & Tuyere and iron slag \\
\hline 268004 & J6 & AMS/charcoal & $1570 \pm 40 \mathrm{BP}$ & $\mathrm{AD} 402-572$ & Tuyere and iron slag \\
\hline \multicolumn{6}{|c|}{ SPIT 6} \\
\hline 255955 & D6 & AMS/charcoal & $1700 \pm 40 \mathrm{BP}$ & $\mathrm{AD} 246-416$ & $\begin{array}{l}\text { Tuyere, potsherds } \\
\text { and iron slag }\end{array}$ \\
\hline
\end{tabular}

Source: Naizatul Akma (2012); OxCal 4.3. 
Table 3: AMS and radiocarbon dates of site SB2F

\begin{tabular}{|c|c|c|c|c|c|}
\hline Beta & $\begin{array}{l}\text { Trench/ } \\
\text { spit }\end{array}$ & Method/sample & $\begin{array}{l}\text { Conventional } \\
\text { date }\end{array}$ & $\begin{array}{l}\text { Calibrated } \\
\text { date }\end{array}$ & Associated artefacts \\
\hline \multicolumn{6}{|c|}{ SPIT 9} \\
\hline 298598 & G6/9 & AMS/charcoal & $1470 \pm 30 \mathrm{BP}$ & AD 545-645 & Laterites \\
\hline \multicolumn{6}{|c|}{ SPIT 7} \\
\hline 292870 & $\mathrm{~J} 7 / 7$ & AMS/charcoal & $1510 \pm 30 \mathrm{BP}$ & AD 430-622 & $\begin{array}{l}\text { Bricks, tuyere fragments } \\
\text { and iron slag }\end{array}$ \\
\hline 292867 & $\mathrm{H} 8 / 7$ & AMS/charcoal & $1430 \pm 30 \mathrm{BP}$ & AD 575-657 & $\begin{array}{l}\text { Bricks, tuyere fragments } \\
\text { and iron slag }\end{array}$ \\
\hline \multicolumn{6}{|c|}{ SPIT 6} \\
\hline 298591 & M19/6 & AMS/charcoal & $1990 \pm 30 \mathrm{BP}$ & 49 BC-AD 72 & $\begin{array}{l}\text { Iron slag, stonetools and } \\
\text { bricks }\end{array}$ \\
\hline 292868 & $\mathrm{H} 12 / 6$ & AMS/charcoal & $1520 \pm 30 \mathrm{BP}$ & $\mathrm{AD} 428-609$ & $\begin{array}{l}\text { Laterite, tuyere fragments } \\
\text { and iron slag }\end{array}$ \\
\hline 298590 & $\mathrm{G} 7 / 6$ & AMS/charcoal & $1580 \pm 30 \mathrm{BP}$ & $\mathrm{AD} 410-546$ & $\begin{array}{l}\text { Tuyere fragments and iron } \\
\text { slag }\end{array}$ \\
\hline 292871 & G11/6 & $\begin{array}{l}\text { AMS/organic } \\
\text { material }\end{array}$ & $1540 \pm 30 \mathrm{BP}$ & $\mathrm{AD} 426-588$ & $\begin{array}{l}\text { Laterite, tuyere fragments, } \\
\text { iron slag and iron ores }\end{array}$ \\
\hline 298596 & $\mathrm{H} 12 / 6$ & AMS/charcoal & $1500 \pm 30 \mathrm{BP}$ & $\mathrm{AD} 432-639$ & $\begin{array}{l}\text { Bricks, tuyere fragments, } \\
\text { iron ores and iron slag }\end{array}$ \\
\hline 290613 & $\mathrm{H} 8 / 6$ & AMS/charcoal & $1500 \pm 30 \mathrm{BP}$ & $\mathrm{AD} 432-639$ & $\begin{array}{l}\text { Bricks, tuyere fragments, } \\
\text { potsherds and iron slag }\end{array}$ \\
\hline 290614 & $\mathrm{H} 12 / 6$ & AMS/charcoal & $1480 \pm 30 \mathrm{BP}$ & AD 538-645 & $\begin{array}{l}\text { Bricks, tuyere fragments, } \\
\text { iron ores and iron slag }\end{array}$ \\
\hline 298579 & $\mathrm{~K} 7 / 6$ & AMS/charcoal & $1480 \pm 30 \mathrm{BP}$ & AD 538-645 & $\begin{array}{l}\text { Tuyere fragments and iron } \\
\text { slag }\end{array}$ \\
\hline 292869 & $\mathrm{G} 7 / 6$ & AMS/charcoal & $1470 \pm 30 \mathrm{BP}$ & AD 545-645 & $\begin{array}{l}\text { Tuyere fragments and iron } \\
\text { slag }\end{array}$ \\
\hline 292872 & $\mathrm{H} 6 / 6$ & AMS/charcoal & $1470 \pm 30 \mathrm{BP}$ & AD 545-645 & $\begin{array}{l}\text { Tuyere fragments and iron } \\
\text { slag }\end{array}$ \\
\hline 298595 & $\mathrm{~S} 14 / 6$ & $\begin{array}{l}\text { Radiocarbon/ } \\
\text { charcoal }\end{array}$ & $1120 \pm 40 \mathrm{BP}$ & AD 777-1013 & $\begin{array}{l}\text { Tuyere fragments and iron } \\
\text { slag }\end{array}$ \\
\hline \multicolumn{6}{|c|}{ SPIT 5} \\
\hline 298580 & K6/5 & $\begin{array}{l}\text { Radiocarbon/ } \\
\text { charcoal }\end{array}$ & $1630 \pm 50 \mathrm{BP}$ & AD $260-550$ & $\begin{array}{l}\text { Bricks, tuyere fragments } \\
\text { and iron slag }\end{array}$ \\
\hline 298584 & $\mathrm{G} 12 / 5$ & $\begin{array}{l}\text { Radiocarbon/ } \\
\text { charcoal }\end{array}$ & $1600 \pm 40 \mathrm{BP}$ & AD 383-557 & $\begin{array}{l}\text { Tuyere fragments and iron } \\
\text { ores }\end{array}$ \\
\hline 298588 & $\mathrm{~N} 9 / 5$ & AMS/charcoal & $1570 \pm 30 \mathrm{BP}$ & $\mathrm{AD} 416-557$ & $\begin{array}{l}\text { Bricks, tuyere fragments, } \\
\text { potsherds and iron slag }\end{array}$ \\
\hline
\end{tabular}


Table 3: (continued)

\begin{tabular}{|c|c|c|c|c|c|}
\hline Beta & $\begin{array}{l}\text { Trench/ } \\
\text { spit }\end{array}$ & Method/sample & $\begin{array}{c}\text { Conventional } \\
\text { date }\end{array}$ & $\begin{array}{l}\text { Calibrated } \\
\text { date }\end{array}$ & Associated artefacts \\
\hline 290612 & G9/5 & AMS/charcoal & $1510 \pm 30 \mathrm{BP}$ & AD $430-622$ & $\begin{array}{l}\text { Tuyere fragments and iron } \\
\text { slag }\end{array}$ \\
\hline 298594 & $\mathrm{~K} 13 / 5$ & AMS/charcoal & $1510 \pm 30 \mathrm{BP}$ & AD $430-622$ & $\begin{array}{l}\text { Laterite and tuyere } \\
\text { fragments }\end{array}$ \\
\hline 292866 & G9/5 & AMS/charcoal & $1490 \pm 30 \mathrm{BP}$ & AD 436-644 & $\begin{array}{l}\text { Tuyere fragments and iron } \\
\text { slag }\end{array}$ \\
\hline 298587 & $\mathrm{H} 7 / 5$ & AMS/charcoal & $1480 \pm 30 \mathrm{BP}$ & AD 538-645 & $\begin{array}{l}\text { Bricks, tuyere fragments } \\
\text { and iron slag }\end{array}$ \\
\hline \multicolumn{6}{|c|}{ SPIT 4} \\
\hline 298597 & $\mathrm{~K} 18 / 4$ & AMS/charcoal & $1490 \pm 30 \mathrm{BP}$ & AD 436-644 & $\begin{array}{l}\text { Laterite, tuyere fragments, } \\
\text { iron ores and iron slag }\end{array}$ \\
\hline 298589 & V10/4 & $\begin{array}{l}\text { Radiocarbon/ } \\
\text { charcoal }\end{array}$ & $1330 \pm 40 \mathrm{BP}$ & AD $643-770$ & $\begin{array}{l}\text { Bricks and tuyere } \\
\text { fragments }\end{array}$ \\
\hline 298586 & W10/4 & $\begin{array}{l}\text { Radiocarbon/ } \\
\text { charcoal }\end{array}$ & $1140 \pm 40 \mathrm{BP}$ & AD 775-985 & $\begin{array}{l}\text { Bricks, tuyere fragments } \\
\text { and iron slag }\end{array}$ \\
\hline 290615 & $\mathrm{~T} 12 / 4$ & AMS/charcoal & $970 \pm 30 \mathrm{BP}$ & AD 1016-1155 & $\begin{array}{l}\text { pebbles, tuyere fragments, } \\
\text { iron slag and iron ores }\end{array}$ \\
\hline \multicolumn{6}{|c|}{ SPIT 3} \\
\hline 298592 & $\mathrm{~K} 10 / 3$ & AMS/charcoal & $1720 \pm 30 \mathrm{BP}$ & AD 248-391 & $\begin{array}{l}\text { Tuyere fragments, pebbles } \\
\text { iron slag and furnace } \\
\text { remains }\end{array}$ \\
\hline 298585 & M16/3 & AMS/charcoal & $1510 \pm 30 \mathrm{BP}$ & $\mathrm{AD} 430-622$ & $\begin{array}{l}\text { Pebbles, tuyere fragments, } \\
\text { iron slag and iron ores }\end{array}$ \\
\hline 298593 & W11/3 & $\begin{array}{l}\text { Radiocarbon/ } \\
\text { charcoal }\end{array}$ & $1210 \pm 40 \mathrm{BP}$ & AD 687-940 & $\begin{array}{l}\text { Bricks, tuyere fragments } \\
\text { and iron slag }\end{array}$ \\
\hline 298583 & $\mathrm{M} 4 / 3$ & AMS/charcoal & $460 \pm 30 \mathrm{BP}$ & AD $1412-1468$ & $\begin{array}{l}\text { Laterite, tuyere fragments, } \\
\text { ceramics, bricks and iron } \\
\text { slag }\end{array}$ \\
\hline
\end{tabular}

Source: Naizatul Akma (2019); OxCal 4.3 
Table 4: AMS and radiocarbon dates of site SB1ZY and SB1G

\begin{tabular}{lccccl}
\hline Beta & $\begin{array}{c}\text { Trench/ } \\
\text { spit }\end{array}$ & Method/sample & $\begin{array}{c}\text { Conventional } \\
\text { date }\end{array}$ & $\begin{array}{c}\text { Calibrated } \\
\text { date }\end{array}$ & Associated artefacts \\
\hline 344762 & E6/4 & AMS/charcoal & SB1ZY & & \\
344763 & G6/5 & $\begin{array}{c}\text { Radiocarbon/ } \\
\text { charcoal }\end{array}$ & $2210 \pm 30 \mathrm{BP}$ & BC 380-200 & Laterite and bricks \\
344765 & F7/8 & AMS/charcoal & $1700 \pm 30 \mathrm{BP}$ & AD 250-410 & $\begin{array}{l}\text { Laterite, bricks and tuyere } \\
\text { fragments }\end{array}$ \\
344764 & J12/7 & AMS/charcoal & $1610 \pm 30 \mathrm{BP}$ & AD 390-540 & Tuyere fragments and bricks \\
\hline 516415 & G14/8 & AMS/charcoal & $1150 \pm 30 \mathrm{BP}$ & AD 776-971 & $\begin{array}{l}\text { Tuyere Fragments, iron ores, } \\
\text { laterite, bricks and iron slags }\end{array}$ \\
516416 & E9/8 & AMS/charcoal & $1620 \pm 30 \mathrm{BP}$ & AD 382-538 & $\begin{array}{l}\text { Tuyere Fragments, iron ores, } \\
\text { bricks and iron slag }\end{array}$ \\
516414 & G15/10 & AMS/charcoal & $1280 \pm 30 \mathrm{BP}$ & AD 662-774 & $\begin{array}{l}\text { Tuyere Fragments, iron ores, } \\
\text { laterite, bricks and iron slag }\end{array}$ \\
\hline
\end{tabular}

Source: Naizatul Akma (2019).

Table 5: OSL and radiocarbon dates of site SB1A, SB2B, SB2D and SB1Y

\begin{tabular}{|c|c|c|c|c|c|}
\hline $\begin{array}{l}\text { Sample number/ } \\
\text { code }\end{array}$ & Spit & Method & Sample & Convensional date & Calibrated date \\
\hline \multicolumn{6}{|c|}{ SB1A } \\
\hline $90-250 \mu \mathrm{m}$ & 5 & OSL & Brick & $1.74 \pm 0.26 \mathrm{ka}$ & AD 269 \\
\hline \multicolumn{6}{|c|}{ SB2B } \\
\hline Beta 290605 & 5 & Radiocarbon & Charcoal & $1450 \pm 30$ B.P & AD $560-650$ \\
\hline- & 5 & OSL & Brick & $1.3 \pm 0.1 \mathrm{ka}$ & AD 718 \\
\hline Beta 290607 & 8 & Radiocarbon & Charcoal & $1560 \pm 30$ B.P & AD $420-570$ \\
\hline \multicolumn{6}{|c|}{ SB2D } \\
\hline Beta 290608 & 4 & Radiocarbon & Charcoal & $950 \pm 30$ B.P & AD $1020-1160$ \\
\hline Beta 277030 & 6 & Radiocarbon & Charcoal & $1110 \pm 40$ B.P & AD $870-1010$ \\
\hline- & 6 & OSL & Brick & $1.8 \pm 0.2 \mathrm{ka}$ & AD 218 \\
\hline Beta 277031 & 7 & Radiocarbon & Charcoal & $1330 \pm 40$ B.P & AD $640-770$ \\
\hline Beta 277034 & 8 & Radiocarbon & Charcoal & $1580 \pm 40$ B.P & AD $420-600$ \\
\hline \multicolumn{6}{|c|}{ SB1Y } \\
\hline- & 8 & OSL & Brick & $1.9 \pm 0.2 \mathrm{ka}$ & AD 119 \\
\hline
\end{tabular}

Sources: Zolkarnian, Chia and Hamid (2011); Iklil Izzati (2014); Mohd Hasfarisham (2019) 


\section{REFERENCES}

Allen, J.S. 1988. Trade transportation and tibutaries: Exchange, agriculture, and settlement distribution in early historic period Kedah, Malaysia. PhD diss., University of Hawaii.

Bayliss, A. 2009. Rolling out revolution: Using radiocarbon dating in archaeology. Radiocarbon 51(1): 123-147.

Bellina, B. 2016. The inception of the trans-national processes between the Indian Ocean and the South China Sea from an early city-state on the Thai-Malay Peninsula (fourth-second century BCE). In The ports of the Ancient Indian Ocean, eds. M.F. Boussac, J.F. Salles and J.B. Yon, 1761-1772. India: Primus Books.

. 2018. Development of maritime trade polities and diffusion of the "South China Sea sphere of interaction pan-regional culture": The Khao Sek excavations and industries studies contribution. Archaeological Research in Asia 13: 1-12. https://doi.org/10.1016/j.ara.2017.06.004

Bellina, B. and I.C. Glover. 2004. The archaeology of early contacts with India and the Mediterranean world from the fourth century BC to the fourth century AD. In Southeast Asia, from the prehistory to history, eds. I.C. Glover and P. Bellwood, 68-89. London: Routledge/Curzon.

Bellina, B. and P. Silapanth. 2006. Weaving cultural identities on trans-Asiatic networks: Upper Thai-Malay Peninsula - an early socio-political landscape. Bulletin de l'Ecole française d'Extrême-Orient. Tome 93: 257-293. https://doi.org/10.3406/ befeo.2006.6039

Bellina B., P. Silapanth, C. Boonyarit, C. Thongcharoenchaikit., J.A. Allen, V. Bernard, B. Borrel, et al. 2014. The development of coastal polities in the Upper ThaiMalay Peninsula in the late first millennium BCE. In Before Siam was born: New insights on the art and archaeology of pre-modern Thailand and its neighbouring regions, eds. N. Revire and S. Murphy, 68-89. Bangkok, Thailand: River Books.

Bellwood, P. 2007. Prehistory of the Indo-Malaysian Archipelago. Honolulu: University of Hawaii Press. https://doi.org/10.22459/PIMA.03.2007

Biggs, L., B. Bellina, M. Martinón-Torres and T.O. Pryce. 2013. Prehistoric iron production technologies in the Upper Thai-Malay Peninsula: Metallography and slag inclusion analyses of iron artefacts from Khao Sam Kaeo and Phu Khao Thong. Archaeological and Anthropological Sciences 5: 311-329. https://doi.org/10.1007/s12520-012-0115-2

Borell, B., B. Bellina and B. Chaisuwan. 2014. Contacts between the Upper Thai-Malay Peninsula and the Mediterranean World. In Before Siam was born: New insights on the art and archaeology of pre-modern Thailand and its neighbouring regions, eds. N. Revire and S.A. Murphy, 98-117. Bangkok, Thailand: Rivers book.

Braddell, R. 1989. A study of ancient times in the Malay Peninsula and the Straits of Malacca dan notes of ancient time in Malaya. Malaysian Branch of Royal Asiatic Society (reprint no.7). 
Briggs, L.P. 1950. The Khmer Empire and the Malay Peninsula. The Far Eastern Quarterly 9(3): 256-305. https://doi.org/10.2307/2049556

Buck, C.E. and M. Juarez. 2017. Bayesian radiocarbon modelling for beginners. England: University of Sheffield.

Coedes, G. 1968. The Indianized states of Southeast Asia. Kuala Lumpur: University of Malaya Press.

Colles, B. 1980. Han and Shen-tu China's Ancient relations with South Asia. East and West 30(1/4): 157-177.

Dani, A.H. 1986. Indian palaeography. Oxford: Clarendon Press.

De Kerchove, R. 1948. International maritime dictionary. New Jersey: VanNostrand.

Favereau, A. and B. Bellina. 2016. Thai-Malay Peninsula and South China sea networks (500 BC-AD 200), based on reappraisal of "Sa Huynh-Kalanay"-related ceramics. Quartenary International 416: 219-227. https://doi.org/10.1016/j. quaint.2015.09.100

Farahmasrine Mat Nawi, Norhidayati Mohd Mustaza, Zulfadilah Berhaudin, Mohd Zafri Mahmud and Mokhtar Saidin. 2011. Bukti industri besi di Sungai Batu, Lembah Bujang, Kedah. In Prosiding Seminar Antarabangsa: Mengungkap peradaban Asia Tenggara melalui tapak Padang Lawas, Sumatera dan tapak Sungai Batu, Kedah, eds. Mokhtar Saidin and Suprayitno, 26-40. Indonesia and Malaysia: Unit Pengembangan Riset Fakultas Ilmu Budaya and Pusat Penyelidikan Arkeologi Global USM.

Gaur, A.S., Sundaresh and A.D. Odedra. 2004. New light on the maritime archaeology of Porbandar, Saurashtra Coast, Gujarat. Man and Environment 29(1): 103-107.

Gaur, A.S, Sundaresh and S. Tripati. 2004. An ancient harbour at Dwarka: Study based on the recent underwater explorations. Current Science 86(9): 1256-1260.

. 2006. Recent marine archaeological investigations along the Saurashtra coast, west coast of India. Paper presented at Glimpses of marine archaeology in India: Proceedings of the 7th Indian Conference on Marine Archaeology of Indian Ocean Countries, National Institute of Oceanography, Goa. 6-7 October.

Gaur, A.S. and K.H. Vora. 2007. Ancient technology of jetties and anchoring along the west coast of India. Current Science 93(7): 987-991.

Gooi, L.J. 2018. The development of monuments in Sungai Batu Archaeological Complex, Bujang Valley, Kedah from 500 B.C.E to 1200 C.E. Master's diss., Universiti Sains Malaysia.

Hamilton, A.W. 1922. The old Kedah-Patani trade-route. Journal of the Straits Branch of the Royal Asiatic Society 86: 389-393.

Hergoualc'h, M.J. 2002. The Malay Peninsula: Crossroad of the maritime silkroad (100 $B C-1300 A D)$. Leiden: Koninklijke Brill.

Higham, G., C. Higham and A. Kijngam. 2011. Cutting a Gordian knot: The bronze age of Southeast Asia: Origins, timing and impact. Antiquity 85(328): 583-598. https://doi.org/10.1017/S0003598X00067971

Higham, C. and T. Higham. 2015. A new chronological framework for prehistoric Southeast Asia, based on a Bayesian model from Ban Non Wat. Antiquity 83(319): 125-144. https://doi.org/10.1017/S0003598X00098136 
Hsiao, C.H. and P. Bellwood. 2010. Movement of raw materials and manufactured goods across the South China Sea after 500 BCE: From Taiwan to Thailand, and back. In 50 years of archaeology in Southeast Asia: Essays in Honour of Ian Glover, eds. B. Bellina, E.A. Bacus, T.O. Pryce and J. Wisseman-Christie, 235-245. Canberra: Australian National University.

Hudson, B. 2012. A thousand years before bagan: Radiocarbon dates and Myanmar's Ancient Pyu cities. In Early Myanmar and its global connections, eds. G.Y. Goh and J.N. Miksic, 88-121. Singapore: ISEAS-Yusof Ishak Institute.

Iklil Izzati Zakaria. 2014. Kajian arkeologi di tapak jeti SB2B dan SB2D, Kompleks Sungai Batu, Lembah Bujang. Master's diss., Universiti Sains Malaysia, Penang, Malaysia.

Johansen, P.G. 2014. Early ironworking in iron age South India: New evidence for the social organization of production from northern Karnataka. Journal of Field Archaeology 39(3): 256-274. https://doi.org/10.1179/0093469014Z .00000000086

Källén, A. 2004. Through flows the river: Archaeology and the pasts of Lao Pako. PhD diss., Uppsala University.

Khoo, T.T. 1996. Geomorphological evolution of the Merbok Estuary area and its impact on the early state of Kedah, Northwest Peninsular Malaysia. Journal of Southeast Asian Earth Sciences 13: 247-368. https://doi.org/10.1016/0743 $-9547(96) 00042-6$

Lamb, A. 1961. Miscellanous papers on early Hindu and Buddhist settlement in Northern Malaya and Southern Thailand. Federation Museums Journal VI: 90.

Leong, S.H. 1989. Satu perbincangan mengenai peninggalan objek-objek gangsa kecil dari zaman prasejarah Malaysia. Jurnal Arkeologi Malaysia 2: 1-8.

Linehan, W. 1951. Traces of the Bronze Age culture associated with Iron Age in the regions of Klang and the Tembeling. Journal of the Malayan Branch of the Royal Asiatic Society XXVI(3): 1-59.

Low, J. 1849. On an inscription from Keddah. Journal of Asiatic Society of Bengal XVIII(1): 247.

Lowenstein, P.J. 1956. The origin of the Malayan Metal Age. Journal of the Malayan Branch of the Royal Asiatic Society XXIX(2): 5-78.

Manguin, P.Y. 2000. City states and citi state cultures in pre-15th century Southeast Asia. In A comparative study of thirty city-state cultures: An investigation conducted by Copenhagen Polis Centre, ed. M.H. Hansen, 409-416. Copenhagen: C.A. Reitzel Forlag.

Mohd Hasfarisham Abd Halim. 2014. Ekskavasi tapak senibina jeti SB2E, SB1H, SB1J, SB1K dan SB1L di Kompleks Sungai Batu, Lembah Bujang, Kedah. Master's diss., Universiti Sains Malaysia.

2019. Sumbangan kajian di tapak SB1Y, SB2G, SB2J dan SB2ZZ kepada bukti seni bina pelabuhan di Kompleks Sungai Batu Lembah Bujang, Kedah. PhD diss., Universiti Sains Malaysia.

Mokhtar Saidin. 2016. Kedah Tua Kingdom: New evidence from Sungai Batu Complex. Paper presented in Kedah Tua International Conference, Sungai Petani, Kedah. 21-22 May. 
Naizatul Akma Mohd Mokhtar. 2012. Ekskavasi tapak peleburan besi SB2A, Sungai Batu, Lembah Bujang. Master's diss., Universiti Sains Malaysia.

2019. Kajian kompleks peleburan besi di Kompleks Sungai Batu, Lembah Bujang daripada perspektif arkeometallurgi. PhD diss., Universiti Sains Malaysia.

Naizatul Akma Mohd Mokhtar and Mokhtar Saidin. 2019. Artifak besi dalam industri besi Sungai Batu, Lembah Bujang. In Arkeologi Kedah Tua: Sumbangan data terkini dari perspektif warisan, seni \& budaya, eds. Suresh Narayanan, Nasha Rodziadi Khaw and Mokhtar Saidin, 17-32. Pulau Pinang: Centre for Global Archaeological Research, Universiti Sains Malaysia.

Nasha Rodziadi Khaw. 2011. Pensejarahan Kedah Tua: Satu analisis sosioekonomi. Master's diss., Universiti Sains Malaysia.

Nasha Rodziadi Khaw, Nazarudin Zainun and Mokhtar Saidin. 2017. Kedah Tua: Satu cerakinan sumber India. Jurnal Arkeologi Malaysia 30(2): 11-20.

Nik Hassan Shuhaimi Nik Abdul Rahman. 1984. Art, archaeology and the early kingdoms in the Malay Peninsula and Sumatra: c. 400-1400 AD. PhD diss., University of London.

Nik Hassan Shuhaimi Nik Abdul Rahman and Othman Mohd Yatim. 1992. Warisan Lembah Bujang, Selangor: Universiti Kebangsaan Malaysia.

Nilakantha Sastri, K.A. 1975. The Colas. Madras: The University of Madras.

Nitta, E. 1997. Iron-smelting and salt-making industries in Northeast Thailand. Bulletin of the Indo-Pacific Prehistory Association 16: 153-160. https://doi.org/10.7152/ bippa.v16i0.11656

Nordianah Molinka. 2013. Teknologi peleburan besi di tapak SB2C, Sungai Batu, Lembah Bujang, Kedah: Abad ke-8 hingga ke-11 masihi. Master's diss., Universiti Sains Malaysia.

Norhidayahti Mohd Muztaza. 2015. Kajian arkeologi di Tapak Kampung Chemara dan Kampung Sungai Perahu, Jeniang, Kedah. Master's diss., Universiti Sains Malaysia.

Nurashiken Ahmad. 2016. Kajian arkeologi di tapak SB1R, SB1S, SB1T, SB1U, SB1V dan SB1Z di Kompleks Sungai Batu, Lembah Bujang, Kedah. Master's diss., Universiti Sains Malaysia.

Petchey, P., B. Bellina, T.O. Pryce and J. Innanchai. 2018. A late prehistoric iron smithing workshop and associated iron industry at the Port Settlement of Khao Sek, Thai-Malay Peninsula. Archaeological Research in Asia 13: 59-73.

Pillai, J.M.S. 1968. A history of Tamil literature with texts and translations from the earliest times to 600 A.D. Annamalainagar: J.M.S. Pillai.

Prakash, B. 2011. Ancient Indian iron and steel: An archaeometallurgical study. Indian Journal of History of Science 46(3): 381-410.

Pryce, T.O., M. Murillo-Barroso, B. Bellina and M. Martinón-Torres. 2010. Khao Sam Kaeo - An archaeometallurgical crossroads for trans-Asiatic technological traditions. Journal of Archaeological Science 37(7): 1761-1772. https://doi .org/10.1016/j.jas.2010.01.036 
Pryce, T.O., M. Brauns, N. Chang, E. Pernicka, M. Pollard, C. Ramsery, T. Rehren, et al. 2011. Isotopic and technological variation in prehistoric primary Southeast Asian copper production. Journal of Archaeological Sciences 38: 3309-3322. https://doi.org/10.1016/j.jas.2011.07.016

Pryce, T.O. 2014. Metallurgy in Southeast Asia. Encyclopaedia of the History of Science, Technology, and Medicine in Non-Western Cultures 134: 1-17. https://doi.org/10.1007/978-94-007-3934-5_10178-1

Pryce, T.O., B. Bellina and A. T. N. Bennett. 2006. The development of metal technologies in the Upper Thai-Malay Peninsula: Initial interpretation of the archaeometallurgical evidence from Khao Sam Kaeo. Bulletin de l'École française d'Extrême-Orient 93: 295-315. https://doi.org/10.3406/befeo.2006 .6040

Quaritch-Wales, H.G. 1940. Archaeological research on Ancient Indian colonization in Malaya. Journal of the Malayan Branch of the Royal Asiatic Studies 18(1): 1-85.

Ramsey, B.C. 2009. Bayesian analysis of radiocarbon dates. Radiocarbon 51(1): 337-360. https://doi.org/10.1017/S0033822200033865

Rao, K.P. 2018. Iron Age culture in South India: Telangana and Andhra Pradesh. In Iron Age in South Asia, ed. Akinori Eusugi, 129-144. Osaka: Research Group for South Asian Archaeology.

Rispoli, F., R. Ciarla and V.C. Pigott. 2013. Establishing the prehistoric cultural sequence for the Lopburi region, central Thailand. Journal of World Prehistory 26(2): 101-171. https://doi.org/10.1007/s10963-013-9064-7

Rostoker, W. and B. Bronson. 1990. Pre-industrial iron: Its technology and ethnology. Philadelphia: Archeomaterials.

Sasisekaran, B. 2002. Metallurgy and metal industry in Ancient Tamilnadu - An archaeological study. Indian Journal of History of Science 37(1): 17-29.

Sasisekaran, B. and R. Rao. 2001. Iron in Ancient Tamilnadu. In Metallurgy in India: A retrospective, eds. P. Ramachandra Rao and N.G. Goswami, 92-102. New Delhi: India International Publisher.

Schlegel, G. 1899a. To-ho-lo 墮和國 or Tok-ho-lo 獨和羅, Takōla or Takkōla. T'uong Pao 10(2): 155-158. https://doi.org/10.1163/156853299X00183 1899b. Tan-tan 丹丹or Dan-dan 單單 Dondin?. T'uong Pao 10(5): 159-163. https://doi.org/10.1163/156853299X00192

.1899c. Tun-Sun 頓遜 or Tian-Sun 典遜 Tĕnasserim or Tānah-Sāri. T'uong Pao 10(1): 33-38. https://doi.org/10.1163/156853299X00048

Shamsul Anwar Aminuddin. 2016. Kajian arkeologi di tapak SB1M dan SB1N, Kompleks Sungai Batu, Lembah Bujang, Kedah. Master's diss., Universiti Sains Malaysia.

Shamsul Anwar Aminuddin, Akmahazila Ab Ghani and Mokhtar Saidin. 2011. Senibina di Kedah Tua: Bukti daripada tapak SB2G'10, SB1M'10 and SB1N'11. In Prosiding Seminar Antarabangsa: Mengungkap peradaban Asia Tenggara melalui tapak Padang Lawas, Sumatera dan tapak Sungai Batu, Kedah, eds. Mokhtar Saidin and Suprayitno, 82-105. Indonesia and Malaysia: Unit Pengembangan Riset Fakultas Ilmu Budaya and Pusat Penyelidikan Arkeologi Global USM. 
Sitthithaworn, E. 1990. Metallogenic map of Thailand. Bangkok: Department of Mineral Resources.

Siti Nurul Siha Mohamad. 2014. Ekskavasi tapak SB1C, SB1D, SB1E, dan SB1F di Sungai Batu, Lembah Bujang, Kedah. Master's diss., Universiti Sains Malaysia.

Sieveking, de G. 1956. The Iron Age collections of Malaya. Journal of the Malayan Branch of the Royal Asiatic Society 29(2): 79-138.

Skilling, P. 2018. Sāgaramati-paripṛcchā Inscriptions from Kedah, Malaysia. In Reading slowly: A Festschrift for Jens E. Braarvig, eds. L. Edzard, J.W. Borgland and U. Hüsken, 433-460. Wiesbaden: Harrassowitz Verlag. https://doi.org/10.2307/ j.ctvckq4dr.33

Sudyka, J. 2011. The "Megalithic" Iron Age culture in South India: Some general remarks. Analecta Archaeologica Ressoviensia 5: 359-389.

Suhana Yusof. 2016. Ekskavasi tapak monumen SB1P, SB1Q, SB1W dan SB1X di Kompleks Sungai Batu, Lembah Bujang, Kedah. Master's diss., Universiti Sains Malaysia.

Tibbetts, G.R. 1978. A study of the Arabic texts containing materials on South East Asia. Leiden: E.J. Brill.

Wheatley, P. 1956a. Tun-Sun (頓 遜). Journal of the Royal Asiatic Society of Great Britain and Ireland 1/2: 17-30. https://doi.org/10.1017/S0035869X00114431 . 1956b. Langkasuka. T'oung Pao, Second Series 44(4/5): 387-412. https://doi .org/10.1163/156853256X00126

1966. The golden Khersonese. Kuala Lumpur: University of Malaya Press.

Wilkinson, R.J. 1939. The Bernam slab-graves. Journal of the Malayan Branch of the Royal Asiatic Society 17(1): 134-143.

Wolters, O.W. 1989. Perdagangan awal Indonesia. Kuala Lumpur: Dewan Bahasa dan Pustaka.

Yasuyuki, M. 2009. Iron production in Han and pre-Han periods in Sichuan Cheng Du Plain China. Paper presented at World of Iron Conference, London. 16-20 February.

Zolkarnian Hassan, S. Chia and Hamid Mohd Isa. 2009. Survey and excavation of an ancient monument in Sungai Batu, Bujang Valley, Kedah, Malaysia. In Bujang Valley and early civilisations in Southeast Asia, eds. S. Chia and B.W. Andaya, 28-49. Kuala Lumpur: Department of National Heritage Malaysia.

. 2011. Survey and excavation of an ancient monument in Sungai Batu, Bujang Valley, Kedah, Malaysia. In Bujang Valley and early civilisations in Southeast Asia, eds. S. Chia and B.W. Andaya, 27-50. Kuala Lumpur: Department of Herigate Ministry of Information, Communications and Culture Malaysia.

Zuliskandar Ramli. 2012. Proses akulturasi budaya India dan transformasil ilmu masyarakat Melayu Kedah Tua berdasarkan data arkeologi dan kajian saintifik. $\mathrm{PhD}$ diss., Universiti Kebangsaan Malaysia.

Zuliskandar Ramli and Nik Hassan Shuhaimi Nik Abdul Rahman. 2010. Petempatan masyarakat Zaman Logam di Selangor berdasarkan data arkeologi. International Journal of Malay World and Civilisation 28(1): 41-55. 
Zuliskandar Ramli, Nik Hassan Shuhaimi Nik Abdul Rahman, Sharifah Nur Izzati Syed Hassan, Ros Mahwati Ahmad Zakaria, Mohd Rohaizat Abdul Wahab, Norlelawaty Haron and Hasnira Hassan. 2014. Sungai Mas, Kuala Selinsing dan Santubong: Pusat pengeluaran manik kaca Indo-Pasifik di Asia Tenggara pada Zaman Protosejarah. In Isu-isu sains \& teknologi di Alam Melayu, eds. Abdul Latif Samian and Nazri Muslim, 370-392. Selangor: Universiti Kebangsaan Malaysia.

Zuliskandar Ramli, Nik Hassan Shuhaimi Nik Abdul Rahman, Adnan Jusoh and Muhammad Rizal Razman. 2014. Interpretasi terkini data arkeologi di Kompleks Percandian Pengkalan Bujang, Kedah. International Journal of the Malay World and Civilisation (IMAN) 2(2): 81-90.

Zvelebil, K. 1973. The smile of Murugan on the Tamil literature of South India. Leiden: E.J. Brill. 1975. Tamil literature. Leiden: E.J. Brill. 